\title{
Türkiye’de Piyano İle İlgili Yapılan Lisansüstü Araştırmaların İçerik
}

\author{
Analizi: (1995-2017)*
Content Analysis Related to the Graduate Research on the Piano in Turkey: (1995- 2017)

\author{
Doç. Dr. Ezgi BABACAN (iD 1
}

\begin{abstract}
$\ddot{O} z$
Bilimsel araştırmalar sistematik şekilde belirli bir yöntemle bilgilerin toplanması, çözümlenmesi ve yorumlanarak raporlaştırılması sürecine dayanmaktadır. Bu süreçte araştırma sonuçları tez, makale gibi farklı yayın türleriyle paylaşılabilmektedir. Alana yönelik yapılan her araştırma sonucunda ortaya çıkan yaklaşım ve uygulamalar o disipline olumlu katkı sağlamaktadır. Piyano ile ilgili yapılan lisansüstü araştırmaların sistematik olarak incelenmesi amacıyla yapılan bu çalışma, piyanoya yönelik yapılan çalışmaların genel bir çerçevede raporlaştırılması, sistematik olarak düzenlenmesi ve yapılacak yeni çalışmalar için araştırmacılara yardımcı olması açısından önemli görülmektedir. Araştırmada 1987-2017 arasında, YÖK tez merkezi veritabanında tam metin PDF olarak ulaşılan ve konu içeriği doğrudan piyano ile ilgili tezler incelenerek içerik analiziyle çözümlenmiştir. Araştırma kapsamında belirlenen tarama ve seçim ölçütleriyle kullanılacak lisansüstü araştırmalar belirlenmiş ve konu içeriği piyano ile ilgili olanlar örnekleme dahil edilmiş̧ir. Araştırma örnekleminde yer alan lisansüstü araştırmalar incelenmiş, excel programı kullanılarak kodlanmış ve araştırma türünden başlayarak, 17 maddeden oluşan temalar incelenmiştir.
\end{abstract}

Anahtar Kelimeler: Piyano, lisansüstü tez, bilimsel araştırma, içerik analizi

Makale Türü: Araştırma

\begin{abstract}
Scientific researches are based on the process of systematically collecting, analyzing, and reporting by interpreting information with a specific method. In this process, research results can be shared with different types of publications such as thesis and article. The approaches and practices that emerge as a result of every research conducted in the field contribute positively to that discipline. This study, which was carried out to systematically examine the graduate studies on piano, is considered important in terms of reporting the studies on piano, in a general framework, organizing them systematically, and helping researchers for new studies to be made. In the research, between 1987 and 2017, the theses that were accessed as full text PDF in the YÖK thesis center database and the content of the subject were analyzed by content analysis by examining the piano directly. With the screening and selection criteria determined within the scope of the research, the graduate studies to be used were determined and the subjects related to piano were included in the sample. Postgraduate studies included in the research sample were examined, coded using the excel program, and themes consisting of 17 items starting from the research type were examined.
\end{abstract}

Keywords: Piano, graduate thesis, scientific research, content analysis

Paper Type: Research

\footnotetext{
* Bu çalışma 17-19 Temmuz 2017 tarihinde Kıbrıs Doğu Akdeniz Üniversitesinde düzenlenen “Uluslararası 3. İpek Yolu Müzik Konferansı"nda sözlü bildiri olarak sunulmuştur.

${ }^{1}$ Necmettin Erbakan Üniversitesi, Eğitim Fakültesi Müzik Eğitimi Anabilim Dalı, ezgibabacan@hotmail.com

Atıf için (to cite): Babacan, E. (2021). Türkiye'de Piyano ile İlgili Yapılan Lisansüstü Araştırmaların İçerik Analizi: (1995-2017). Afyon Kocatepe Üniversitesi Sosyal Bilimler Dergisi, 23(3), 1159-1191.
} 


\section{Giriş}

Bilimsel araştırmalar sistematik şekilde belirli bir yöntemle bilgilerin toplanması, çözümlenmesi ve yorumlanarak raporlaştırılması sürecine dayanmaktadır. Bu süreçte yapılan araştırma sonuçları tez, makale gibi farklı yayın türleriyle paylaşılabilmektedir. Bilimsel araştırmaların eğitsel olarak başladığı ilk basamak şüphesiz ki lisansüstü eğitim sürecidir. $\mathrm{Bu}$ süreçte alana özgü bilgi ve becerileri kazanmak ve artırmak için, bilgiyi araştırmak, analiz etmek, yorumlamak ve farklı araştırma alanı ile karşılaştırmak önemlidir. Ülkemizde mesleki olarak sanat eğitimi veren tüm yükseköğretim kurumları 1982'de yürürlüğe giren kararname ve 1983 'te onun yerini alan 2809 sayılı yasa ile YÖK kapsamına alınarak üniversitelere bağlanmıştır. Yine 1982 yılındaki 'Lisansüstü Öğretim Yönetmeliği' ile bu alanda lisansüstü eğitim başlamıştır (Uçan, 1996, s.193-199). YÖK'ün (2016) lisansüstü eğitim öğretim yönetmeliği içerisinde yüksek lisans programı, öğrencinin bilimsel araştırma yöntemlerini kullanarak bilgilere erişme, bilgiyi derleme, yorumlama ve değerlendirme yeteneğini kazanmasını sağlamak olarak tanımlanmaktadır. Doktora programı, öğrenciye bağımsız araştırma yapma, bilimsel problemleri, verileri geniş ve derin bir bakış açısı ile irdeleyerek yorum yapma, analiz etme ve yeni sentezlere ulaşmak için gerekli becerileri kazandırmakla; sanatta yeterlik ise, özgün bir sanat eserinin ortaya konulmasını, müzik ve sahne sanatlarında ise üstün bir uygulama ve yaratıcılığ 1 amaçlayan doktora eşdeğeri bir yükseköğretim programı olarak tanımlanmaktadır.

Günümüzde müzik alanında yapılan lisansüstü araştırmalar, araştırma alanına göre çok çeşitli olabilmektedir. Ülkemizde müzik eğitimi, konservatuar, müzik bilimleri, müzikoloji ve müzik öğretmenliği gibi farklı programlarda verilmektedir. Mesleki alanda düşünüldüğünde (Uçan, 2005) üniversitelerin eğitim fakültelerine bağlı, müzik eğitimi anabilim dalları, müzik eğitimciliği yönünde, rektörlük bünyesinde devlet konservatuvarları seslendiricilik, bestecilik çalg1 yapımcılık ve onarıcılık yönünde, Güzel sanatlar fakülteleri müzik bölümleri ise müzik alanında araştırma yaparak lisans, yüksek lisans, doktora ve sanatta yeterlik boyutlarında akademik eğitim ve araştırma programlarının geliştirilmesinde kapsamlı ve önemli görevler yüklenmiştir (aktaran: Sonsel, 2018, s.342). Milli Eğitim Bakanlığı Strateji Geliştirme Başkanlığ 1 verileri doğrultusunda Türkiye genelinde 2014 yılında yapılan araştırmada (Öztürk ve Dinç, 2016) lisansüstü eğitim almış müzik öğretmeni sayıs1 996 olarak belirlenmiş, bunların 536'sının tezli yüksek lisans, 448'inin tezsiz yüksek lisans ve 12'sinin doktora tezi olduğu saptanmiştır.

Ülkemizde müzik alanında lisansüstü araştırmaların incelenmesine yönelik farklı alanları (müzik bilimleri, müzik öğretmenliği vb.), branşları (gitar, flüt, viyola, keman vb.) kapsayan araştırmalar (Demirbatır, 2001; Ataman, 2009; Karkın, 2011; Orhan, 2012; Tebiş ve Okay, 2013; Çeşit, 2015; Alyörük, 2016; Öztutgan, 2016; Öztürk ve Dinç, 2016; Sonsel, 2018; Soycan ve Babacan, 2019) bulunmaktadır. Örneğin, Demirbatır (2001), bibliyografya çalışmasında Yükseköğretim Kurulu dokümantasyon merkezinden aldığı, 1985-2000 yılları arasında yapılmış, doğrudan ya da dolaylı olarak müzik alanı ile bağlantılı 199 yüksek lisans, 29 doktora ve 12 sanatta yeterlik tezinin yer aldığını belirtmiştir. Karkın (2011) ise, 1989-1999 yılları arasında müzik bilimleri alanında yapılmıs lisansüstü tezleri incelediği aratırmasında Yükseköğretim Kurulu'nun tez arşivinde 107 yüksek lisans, 21 doktora ve 6 sanatta yeterlik tezlerine ulaşmıştır. Farklı branşlarda araştırmalardan örneğin Orhan (2012) sadece viyolonsel alanında Türkiye'de 1992-2011 yılları arasında, 21 farklı üniversitede 60 yüksek lisans, 10 doktora ve 5 sanatta yeterlilik tezinin yer aldığını belirtmiştir. Tebiş ve Okay (2013) 1989-2012 yılları arası keman ve viyola konulu lisansüstü tezleri incelediği araştırmasında, 22 farklı üniversitede 172'si yüksek lisans, 28'i sanatta yeterlik ve 24'ü doktora olmak üzere 224 tezin yapılmış olduğunu tespit etmiştir. Alyörük (2016) gitar ile ilgili araştırmasında, YÖK Tez Merkezinde taranan, 1986-2015 yılları arasında Türkiye'de 120 araştırmadan 89'unun yüksek lisans, 23'ünün doktora ve 8'inin sanatta yeterlik tezi olduğunu saptamıştır. Sonsel (2018) 
araştırmasında 1994-2017 seneleri arasında viyola alanında 41'i yüksek lisans, 14'ü sanatta yeterlik ve 2'si doktora tezi olmak üzere 57 tezi incelemiştir.

Müziğin öğretiminde en yaygın ve yararlı çalgılardan biri olan piyano, sabit perdeli, entonasyon zorluğu ve bozukluğu olmayan, ses sınırı geniş ve her türlü ajilitenin yapılabildiği, armonik-polifonik bir eşlik çalgısıdır (Yönetken, 1996, s.69). Sanat eğitiminin bir kolu olan müzik eğitiminde piyano branşı ülkemizde amaca, kapsama ve içeriğe göre farklı şekillerde düzenlenmektedir. Profesyonel boyutta piyanist yetiştirmek amacından başlayarak, müzik bilimcisi, müzikolog, müzik eğitimcisi vb. gibi çok farklı alanlarda hem eğitim aracı hem de iyi bir eşlik çalgısı olarak kullanılmaktadır. Alan eğitimindeki araştırmalar sonucunda ortaya çıkan yaklaşım ve uygulamalar o alana katkı sağlamaktadır. Piyano ile ilgili yapılan lisansüstü araştırmaların sistematik olarak incelenmesi amacıyla yapılan bu çalışma, piyanoya yönelik yapılan çalışmaların genel bir çerçevede raporlaştırılması, sistematik olarak düzenlenmesi ve araştırmacılara yapılacak yeni çalışmalar için yardımcı olması açısından önemli görülmektedir.

\section{Yöntem}

\subsection{Araştırmanın Modeli}

$\mathrm{Bu}$ araştırma, içerik analizi modelinde tasarlanmış ve veri toplama yöntemi olarak doküman analizi kullanılmıştır. İçerik analizinde yapılan işlem temelde birbirine benzeyen verileri kavramlar ve temalara göre bir araya getirmek ve anlaşılır biçimde düzenleyerek yorumlamaktır (Yıldırım ve Şimşek, 2000, s.162). Özellikle sosyal bilimler alanında sıklıkla kullanılan içerik analizi, belirli kurallara dayalı kodlamalarla bir metnin bazı sözcüklerinin daha küçük içerik kategorileri ile özetlendiği sistematik, yinelenebilir bir teknik olarak tanımlanabilir. İçerik analizi ile kitap, kitap bölümü, mektup, tarihsel dokümanlar, gazete başlıkları ve yazıları hatta görüşme, tartışma, konuşma, sohbet, tiyatro gösteriler de incelenebilir (Büyüköztürk, Kılıç Çakmak, Akgün, Karadeniz ve Demirel, 2008, s.263).

\subsection{Araştırmanın Evren ve Örneklemi}

Araştırma içerisinde kullanılacak lisansüstü çalışmaları belirlemek amacıyla tarama ve seçim ölçütleri belirlenmiş, 06.06.2017 tarihinde bu ölçütlere göre, YÖK tez merkezi veritabanında PDF olarak, 1987-2017 arasında ve başlığında "piyano" bulunan tezler (n:269) içerisinde tam metin olarak ulaşılan ve konu içeriği doğrudan piyano ile ilgili olanlar örnekleme dahil edilmiştir. Araştırma kapsamında incelemeye alınan tezlerden PDF olarak ilk ulaşılabilir olan yıl 1995 olmuştur. Lisansüstü araştırmaları kapsayan tezlerin incelenmesine yönelik yapılan bu araştırmada amaçlı örnekleme yöntemlerinden önceden belirlenmiş ölçütlere göre seçim yapıldığından ölçüt örnekleme kullanılmıştır. Bu örnekleme yöntemi önceden belirlenmiş ölçütleri karşılayan bütün durumların çalışılmasına dayalı temel anlayışa sahiptir. Buradaki ölçütler bir ölçüt listesi olarak daha önceden hazırlanmış olabilir ya da araştırmacı tarafından oluşturulabilir. (Yıldırım ve Şimşek, 2000, s.73). Bu doğrultuda YÖK veri tabanında PDF olarak bulunmayan eski tarihli tezler ile yazar tarafından veritabanında erişime kapatılmış olan tezler (n:19) analiz kapsamı dışında tutulmuştur. Araştırma örnekleminde yer alan (n:250) tezin incelenmesi sonucunda konu kapsamında doğrudan piyano ile ilgili olmayan tezler de (n:14) çıkarılmış ve analiz sürecine geçilmiştir. Araştırmanın içeriğini oluşturan soruların hazırlanmasında daha önceki çalışmalar incelenmiş, kapsam geçerliğini sağlamak amacıyla daha önce içerik analizi çalışması yapmış alan uzmanı başka bir araştırmacı tarafindan bu ölçütlerin araştırma problemini çözmede uygunluğu sorulmuştur. Araştırmacı ve uzman tarafindan değerlendirilen sorular içerisinden 17 alt problemde karar verilmiştir. Analiz sürecinde araştırma örnekleminde yer alan 236 lisansüstü tez (bkz:EK-1) excel programı kullanılarak kodlanmış ve tezler yılı, araştırmacının cinsiyeti, üniversite ve enstitülere göre dağılımı, araştırmanın türü, araştırmanın yöntemi ve deseni, konusu, örneklem grubu, veri toplama aracı ve veri analiz yöntemi, katılımcı sayıs1, deneysel araştırmalarda uygulama yapılan grup, ders, uygulama süresi, deneysel uygulama grubu sayısı ve veri analiz yöntemine göre tablolaştırılarak incelenmiştir. 


\subsection{Verilerin Toplanması ve Analizi}

Araştırmada hedeflenen olgu ve olaylar hakkında bilgi içeren yazılı materyallerin analizini kapsayan doküman incelemesi (Yıldırım ve Şimşek, 2000, s.140) yoluyla elde edilen veriler içerik analizi kullanılarak çözümlenmiştir. Belirlenen ölçütlere uygun olarak lisansüstü tezler incelenerek excel programında tablolaştırmıştır. Sonraki aşamada çalışmaların ölçütlere uygunluğu ve ulaşılabilirliğine göre tekrar incelenerek örneklemde yer alan tezlere karar verilmiş, başka bir araştırmacı tarafından kapsam dışında tutulan tezlerin incelenmesi istenmiş ve bu yolla araştırmanın iç geçerliği ve güvenirliği sağlanmaya çalışılmıştır. Tarama ve ikinci bir uzman görüşü sonucunda konu kapsamına girmeyen 14 tez çıkarılmıştır. Bu tezlerin üç tanesi flüt-piyano eserlerinin flüt icrasına dayalı incelemesi, üç tanesi ses eğitiminde kullanılan piyano eşikli halk türkülerinin incelemesi, ikisi keman piyano sonatında keman çalma tekniği ve müzikal analiz incelemesi, bir tanesi piyano için yazılmış halk türkülerinin iki gitar düzenlemesi, biri yaylı orkestrasında fagot, arp, piyano için konçerto incelemesi, biri obua piyano sonatında obua tekniğinin incelemesi, biri Brahms eserlerindeki korno keman piyano üçlüsünün teknik analizi, biri cazın piyano üzerindeki matematiksel analizi ile fraktal geometri ilişkisi ve son olarak barajların dolu savak kapasitelerini arttırmada kullanılan labirent ve piyano tuşu tipi savakların incelenmesi ile ilgilidir. Araştırma sorularının on tanesi bütün lisansüstü tezleri kapsamakta, ikisi veri analiz birimi ve örneklem grubu olan araştırmaları kapsamakta ve beş tanesi deneysel araştırmaları kapsamaktadır. Araştırma kapsamında yer alan sorular şunlardır:

Lisansüstü tezlerin yıllara göre dağılımı nedir?

Lisansüstü tezlerin yapıldığg üniversitelere göre dağılımı nasıldır?

Lisansüstü tezlerin yapıldığı enstitülere göre dağılımı nasıldır?

Lisansüstü tezleri yapan araştırmacının cinsiyetine göre dağılım nasıldır?

Lisansüstü tezlerin araştırma türüne göre dağılım nasıldır?

Lisansüstü tezlerin araştırma yöntemine göre dağılımı nasıldır?

Lisansüstü tezlerin araştırma desenine göre dağılımı nasıldır?

Lisansüstü tezlerde kullanılan veri toplama araçlarına göre dağılım nasıldır?

Lisansüstü tezlerin örneklem grubuna göre dağılımı nasıldır?

Lisansüstü tezlerde kullanılan veri analiz yöntemine göre dağılım nasıldır?

Lisansüstü tezlerin ortalama katılımcı sayısına göre dağılım nasıldır?

Deneysel araştırmaların uygulama süresi (uygulama sayısı) nedir?

Deneysel araştırmalarda uygulamanın yapıldığı dersler nedir?

Deneysel araştırmalarda uygulamaya katılan katılımcı sayısı nedir?

Deneysel araştırmalardaki uygulama grubu nedir?

Deneysel araştırmalardaki desen nasıldır?

Lisansüstü tezlerin araştırma konusuna göre dağılımı nasıldır?

Bu kategorilere göre içerik analizi yapılan örneklemde yer alan lisansüstü tezler tek tek birkaç kez okunarak temalar oluşturulmuştur. Bu 17 temanın (sorular) her biri için eğer varsa alt temalar da oluşturulmuştur. Örneğin, araştırma deseni içerisinde deneysel ya da betimsel desen kullanan araştırmalar ve alt temaları gerçek deneysel, yarı deneysel desen vb. şeklinde tasarlanmıştır. Temalar oluşturulduktan sonra 236 tez tekrar okunarak mevcut kategori ve temalara göre kodlanmıştır. Bütün kodlamalar bittikten üç gün sonra araştırmacı tarafından kategori ve temalara göre tekrar kodlama yapılmış ve iç tutarlık (güvenirlik) sağlanmaya 
çalışılmıştır. Her iki kodlamadaki tutarlık Miles ve Huberman'ın (1994) güvenirlik formülü kullanılarak hesaplanmış ve uyum yüzdesi \%95 aralığında bulunmuştur. On kodlamadaki farkın birisi enstitü, birisi cinsiyet (her iki cinsiyette de kullanılan ortak ad olduğu için), beşi desen (tezlerde yazılan desen ve yapılan uygulama tutarlı olmadığı için), biri yöntem (yazılan deneysel yöntem ile uygulamada deneysel desen bulunmadığı için) ve ikisi deneysel desendeki uygulama grubu ve sayısı kategorisinde ortaya çıkmıştır. Daha sonra kategoriler ve temalar excel programında kodlanarak tekrarlanma sıklığına göre frekans (f), yüzde (\%), standart sapma ve ortalama değerleri kullanılarak hesaplanmış, tablolaştırılarak yorumlanmıştır.

\section{Bulgular}

$\mathrm{Bu}$ bölümde lisansüstü tezler araştırma yılı, üniversite ve enstitülere göre dağılımı, araştırmacının cinsiyeti, araştırmanın türü, araştırmanın yöntemi ve deseni, konusu, örneklem grubu, veri toplama aracı ve veri analiz yöntemi, katılımcı sayısı, deneysel araştırmalarda uygulama yapılan grup, ders, uygulama süresi, deneysel uygulama grubu sayısı ve veri analiz yöntemine göre tablolar halinde sunulmuş ve yorumlanmıştır.

\subsection{Lisansüstü Tezlerin Yıllara Göre Dağılımı}

Tablo 1. Lisansüstü tezlerin yı1lara göre dağılımı

\begin{tabular}{ccc}
\hline Y11 & $\mathrm{f}$ & $\%$ \\
\hline 1995 & 1 & 0,4 \\
1996 & 1 & 0,4 \\
1997 & 2 & 0,8 \\
1998 & 5 & 1,3 \\
1999 & 3 & 2,5 \\
2001 & 6 & 3,8 \\
2002 & 9 & 2,1 \\
2003 & 5 & 4,7 \\
2004 & 11 & 2,1 \\
2005 & 5 & 7,6 \\
2006 & 18 & 8,1 \\
2007 & 19 & 5,1 \\
2008 & 12 & 9,3 \\
2009 & 22 & 11,9 \\
2010 & 28 & 5,9 \\
2011 & 14 & 5,9 \\
2012 & 14 & 8,5 \\
2013 & 20 & 6,4 \\
2014 & 15 & 5,1 \\
2015 & 12 & 5,5 \\
2016 & 13 & 0,4 \\
2017 & 1 & 100 \\
Toplam & 236 & \\
\hline & & 5,9 \\
\hline
\end{tabular}

Yapılan lisansüstü tezlerin yıllara göre dağılımı incelendiğinde, 1995 ile 2017 yılları arasında PDF olarak ilk ulaşılabilir olanı 1995 yılına aittir. İncelenen 236 çalışmadan 28'inin 2010 yılı (\%11,9), 22'sinin $(\% 9,3) 2009$ y1l1, 20'sinin (\%8,5) 2013 y1lı içerisinde olduğu görülmektedir. Bulgular doğrultusunda, lisansüstü araştırmaların 2010 yılına kadar miktar olarak ciddi artış gösterdiği, 2013 yılından itibaren ise miktarın giderek azaldığı söylenebilir. 


\subsection{Lisansüstü Tezlerin Yapıldığı Üniversiteler}

Tablo 2. Tezlerin yapıldı̆̆ı üniversitelere göre dağılımı

\begin{tabular}{|c|c|c|}
\hline Üniversite & $\mathrm{f}$ & $\%$ \\
\hline Gazi Üniversitesi & 50 & 21,2 \\
\hline Mimar Sinan Üniversitesi & 22 & 9,3 \\
\hline Dokuz Eylül Üniversitesi & 17 & 7,2 \\
\hline Necmettin Erbakan (Selçuk) Üniversitesi & 14 & 5,9 \\
\hline İstanbul Üniversitesi & 12 & 5,1 \\
\hline Marmara Üniversitesi & 12 & 5,1 \\
\hline Trakya Üniversitesi & 12 & 5,1 \\
\hline Hacettepe Üniversitesi & 11 & 4,7 \\
\hline Abant İzzet Baysal Üniversitesi & 9 & 3,8 \\
\hline Erciyes Üniversitesi & 9 & 3,8 \\
\hline Anadolu Üniversitesi & 7 & 3,0 \\
\hline Uludağ Üniversitesi & 6 & 2,5 \\
\hline Atatürk Üniversitesi & 6 & 2,5 \\
\hline İnönü Üniversitesi & 5 & 2,1 \\
\hline Cumhuriyet Üniversitesi & 5 & 2,1 \\
\hline İstanbul Teknik Üniversitesi (İTÜ) & 4 & 1,7 \\
\hline Haliç Üniversitesi & 4 & 1,7 \\
\hline Pamukkale Üniversitesi & 4 & 1,7 \\
\hline Afyon Kocatepe Üniversitesi & 3 & 1,3 \\
\hline Niğde Üniversitesi & 3 & 1,3 \\
\hline Ondokuz Mayıs Üniversitesi & 3 & 1,3 \\
\hline Mehmet Akif Ersoy Üniversitesi & 3 & 1,3 \\
\hline Karadeniz Teknik Üniversitesi & 3 & 1,3 \\
\hline Kocaeli Üniversitesi & 2 & 0,8 \\
\hline Yaşar Üniversitesi & 2 & 0,8 \\
\hline Yüzüncü Y1l Üniversitesi & 1 & 0,4 \\
\hline Süleyman Demirel Üniversitesi & 1 & 0,4 \\
\hline Balıkesir Üniversitesi & 1 & 0,4 \\
\hline Ankara Üniversitesi & 1 & 0,4 \\
\hline Çukurova Üniversitesi & 1 & 0,4 \\
\hline Bilkent Üniversitesi & 1 & 0,4 \\
\hline Yeditepe Üniversitesi & 1 & 0,4 \\
\hline Ordu Üniversitesi & 1 & 0,4 \\
\hline Toplam & 236 & 100,0 \\
\hline
\end{tabular}

Piyano alanında yapılan lisansüstü tezlerin 33 farklı üniversiteye dağıldığ görülmektedir. Buna göre incelenen tezlerin 50'si (\%21,2) Gazi Üniversitesi’nde, 22'si $(\% 9,3)$ Mimar Sinan Üniversitesi'nde, 17'si $(\% 7,2)$ Dokuz Eylül Üniversitesi’nde, 14'ü $(\% 5,9)$ Necmettin Erbakan (Selçuk Üniversitesi) Üniversitesi'nde, 12'si $\quad(\% 5,1)$ İstanbul Üniversitesi’nde, 12'si (\%5,1) Marmara Üniversitesi'nde, 12'si $(\% 5,1)$ Trakya Üniversitesi'nde ve 11 'i $(\% 4,7)$ Hacettepe Üniversitesinde yapılmıştır. Dağılım incelendiğinde ilk sıralarda yer alan üniversitelerin çoğunluğunun ülkemizde müzik alanına yönelik (konservatuar, müzik eğitimi vb.) açılan lisansüstü bölümlerin ilk örnekleri olduğu söylenebilir. Bununla birlikte YÖK tez veri merkezinde piyano anahtar kelimesiyle aramada yer alan ancak tam metine ulaşılamayan tezlerin üniversite dağılımı incelendiğinde ilk tezlerin yıllara göre dağılımı şu şekildedir: Gazi Üniversitesi 1987, Marmara Üniversitesi 1987, İstanbul Üniversitesi 1992, İnönü Üniversitesi 1993, Selçuk Üniversitesi 1996, Hacettepe Üniversitesi 1996, Mimar Sinan Üniversitesi 1996. Analiz sonucunda en fazla lisansüstü tezin Gazi Üniversitesinde olması, tarihsel olarak ülkemizde açılan ilk müzik eğitimi kurumu olması nedeniyle doğal bir sonuçtur. Cumhuriyet tarihimizde 'müzik öğretmeni' yetiştirmek amaciyla Ankara'da 1924 yılında açılan Musiki Muallim Mektebi, orta öğretime öğretmen yetiştirmeyi ve çoksesli müziği eğitime yerleştirmeyi amaçlıyordu. Bu kurum 1936 yılında yeniden yapılandırılarak Gazi Eğitim Enstitüsü'ne bağlandı. 


\subsection{Lisansüstü Tezlerin Yapıldığı Enstitüler}

Tablo 3. Tezlerin enstitülere göre dağılımı

\begin{tabular}{lcc}
\hline & $\mathrm{f}$ & $\%$ \\
\hline Fen Bilimleri Enstitüsü & 9 & 3,8 \\
Sosyal Bilimler Enstitüsü & 113 & 47,9 \\
Eğitim Bilimleri Enstitüsü & 87 & 36,9 \\
Sağllk Bilimleri Enstitüsü & 2 & 0,8 \\
Güzel Sanatlar Enstitüsü & 24 & 10,2 \\
Müzik ve Sahne Sanatları Enstitüsü & 1 & 0,4 \\
\hline Toplam & 236 & 100 \\
\hline
\end{tabular}

Tezlerin yapıldığ $113(\% 47,9)$, eğitim bilimleri enstitüsünde $87(\% 36,9)$, güzel sanatlar enstitüsünde $24(\% 10,6)$, fen bilimleri enstitüsünde $9(\% 3,8)$, sağlık bilimleri enstitüsünde $2(\% 0,8)$, müzik ve sahne sanatları enstitüsünde ise $1(\% 0,4)$ tezin olduğu ve altı farklı enstitüye dağılıdığı görülmektedir. Araştırma kapsamında analiz edilen tezlere göre, Fen bilimleri enstitüsündeki tezlerin biri hariç (Ünal, Z.O. 2008, Marmara Üniversitesi) diğerlerinin 1995-2001 yılları arası yapıldığı, sosyal bilimler enstitüsündeki ilk tezin (Bucak, S., 1995, Mimar Sinan Üniversitesi, sosyal bilimler enstitüsü) 1995 yılında yapıldığı, eğitim bilimleri enstitüsündeki ilk tezin (Çevik, D.B., 2002, Dokuz Eylül Üniversitesi) 2002 yılında yapıldığı, güzel sanatlar enstitüsündeki ilk tezin (Gedikli, A.S., 2006, Dokuz Eylül Üniversitesi) 2006 yılında yapıldığı ve müzik ve sahne sanatları enstitüsünde yapılan tezin (Önal, E., 2005, Bilkent Üniversitesi) 2005 yılında yapıldı̆̆ saptanmıştır. $\mathrm{Bu}$ sonuç doğrultusunda önceden çoğunlukla üniversitelerin fen bilimleri enstitüsünde olan müzik eğitimi veren kurumlar, 2001 yılından itibaren araştırma yaptı̆g 1 bilim alanına göre açılan eğitim bilimleri, sosyal bilimler ve güzel sanatlar enstitülerine bağlandığ söylenebilir. Sağlık bilimleri enstitüsünde yapılan iki tezin (Erdal, G., 2005 ve Zeybek, A., 2013) Beden Eğitimi ve Spor Anabilim Dalı ile Sağlık Bilimleri Fakültesi Fizik Tedavi ve Rehabilitasyon Programında yapıldığı ve piyanoda kas iskelet sistemi ile motorik özelliklere yönelik araştırmalar olduğu saptanmıştır.

\subsection{Lisansüstü Tezlerin Araştırma Türü}

Tablo 4. Tezlerin türüne göre dağılımı

\begin{tabular}{lcc}
\hline & $\mathrm{f}$ & $\%$ \\
\hline Yüksek Lisans & 161 & 68,2 \\
Doktora & 47 & 19,9 \\
Sanatta Yeterlik & 28 & 11,9 \\
\hline Toplam & 236 & 100 \\
\hline
\end{tabular}

Tezlerin araştırma türüne göre dağılım incelendiğinde, yarıdan fazlasının $(\% 68,2)$ yüksek lisans tezlerinden oluştuğu, diğerlerinin ise \%19,9'unun doktora ve \%11,9'unun sanatta yeterlik tezlerinden oluştuğu saptanmıştır. Üniversitelerde ilk olarak açılan genellikle yüksek lisans programı olduğu için ortaya çıkan bu sonuç normal bulunmaktadır. Üniversitelere göre tez türleri dağılımı incelendiğinde 33 üniversiteden 31 'i yüksek lisans programı (2 üniversitede sadece sanatta yeterlik programına ait tez var), 12'si doktora ve 8'i sanatta yeterlik program1 yürütmektedir. Her üç programdan da lisansüstü tez türü olan sadece iki üniversite (Dokuz Eylül ve İstanbul Üniversitesi) bulunmaktadır. Bunun nedeni bu üniversitelerde birden fazla müzik alanına yönelik bölüm (müzik bilimi, müzikoloji, konservatuar, müzik eğitimi vb.) bulunduğu içindir. Ortaya çıkan bir diğer sonuca göre yüksek lisans tezi bitiren araştırmacıların ortalama üçte birinin lisansüstü doktora ve sanatta yeterlik programını bitirdiği söylenebilir. Ulaş1labilir ilk sanatta yeterlik tezinin 1995 y1lında (Bucak, S., 1995, Mimar Sinan Üniversitesi, sosyal bilimler enstitüsü), ilk yüksek lisans tezinin 1996 y1lında (Kalyoncu, N., 1996, Abant İzzet Baysal Üniversitesi, sosyal bilimler enstitüsü) ve doktora tezinin 1997 yılında (Berki, T., 1997, Gazi Üniversitesi, fen bilimleri enstitüsü) yapıldığı saptanmıştır. 


\subsection{Lisansüstü Tezleri Yapan Araştırmacının Cinsiyeti}

Tablo 5. Araştırmacının cinsiyetine göre dağılımı

\begin{tabular}{|c|c|c|c|c|c|}
\hline & & $\mathrm{f}$ & $\%$ & $\mathrm{f}$ & $\%$ \\
\hline & $\overline{Y L}$ & 100 & 67,6 & & \\
\hline \multirow{3}{*}{ Kadın } & DR & 26 & 17,6 & 148 & 62,7 \\
\hline & Sanatta Yeterlik & 22 & 14,9 & & \\
\hline & YL & 61 & 69,3 & & \\
\hline \multirow[t]{2}{*}{ Erkek } & DR & 21 & 23,9 & 88 & 37,3 \\
\hline & Sanatta Yeterlik & 6 & 6,8 & & \\
\hline \multicolumn{2}{|c|}{ Toplam } & & & 236 & 100 \\
\hline
\end{tabular}

Lisansüstü tezlerin cinsiyete göre dağılımı incelendiğinde, tezlerin \%62,7'sinin kadın, \%37,3’ünün ise erkek araştırmacılar tarafından yapıldığı saptanmıştır. Bu sonuca göre, müzik alanında piyano ile ilgili araştırmalara kadın araştırmacıların daha fazla yoğunlaştığı ya da ilgi duyduğu söylenebilir. Tezin türüne göre cinsiyet dağılımı incelendiğinde 161 yüksek lisans tezinden 100'ü $(\% 67,6)$ kadın, 61'i $(\% 69,3)$ erkek araştırmacılar tarafından, 47 doktora tezinden 26 's1 $(\% 17,6)$ kadın, 21'i $(23,9)$ erkek araştırmacılar tarafından ve 28 sanatta yeterlik tezinden 22 'si $(\% 14,9)$ kadın, 6'sı $(\% 14,8)$ erkek araştırmacılar tarafından yapıldığı saptanmıştır. Bu sonuçlara göre yüksek lisans ve sanatta yeterlik tezlerini kadınların daha fazla tercih ettiği söylenebilir.

\subsection{Lisansüstü Tezlerin Araştırma Deseni}

Araştırma desenine göre lisansüstü araştırmalar Saban (2009) tarafından yapılan çoklu zekâ kuramı (ÇZK) ile ilgili Türkçe çalışmaların incelenmesi adlı makalesindeki araştırma deseni ölçütü dikkate alınarak yapılmıştır. Bunun nedeni araştırmaların yöntem ve türleri farklı şekillerde sınıflandırılabilmektedir. Genel olarak araştırmaların amacına, çalışma alanına, zamana, verilerin nicel ya da nitel olmasına ve kullanılan yöntem ve tekniklere göre farklı özellikleri dikkate alınmaktadır (Karakaya, 2014, 58). Bu araştırmada ölçüt alınan desende; herhangi bir alana ilişkin konuyu eleştirel bir yaklaşımla bir bütün olarak ele alan literatür taraması çalışmaları; bir durumu saptamaya ya da açıklamaya yönelik nitel, nicel ve karma yöntemlerin kullanıldığı betimsel araştırmalar; bir uygulamanın etkisini belirmek için nitel, nicel ve karma yöntemlerle gerçekleştirilen deneysel araştırmalar; basılı, görsel vb. materyallerin sistematik bir şekilde belirli kategoriler bakımından tematik olarak analiz eden içerik analizi araştırmaları; uygulamaya dönük materyal, etkinlik, program vb. geliştiren model geliştirme araştırmaları olarak sınıflanmıştır (Saban, 2009, 845).

Tablo 6. Tezlerin araștırma desenine göre dağılımı

\begin{tabular}{lccc}
\hline Araştırmanın Deseni & f & $\%$ \\
\hline Literatür Taraması & & 87 & 36,9 \\
Betimsel Araştırma & & 93 & 39,4 \\
Deneysel Araştırma & & 31 & 12,3 \\
İçerik Analizi Araştırması & & 9 & 3,8 \\
Model Geliştirme & & 7 & 3,0 \\
Saha Araştırması & Betimsel ve Deneysel Araştırma & 1 & 0,4 \\
Karma Araştırmalar & Literatür Taramasi ve Betimsel Araştırma & 7 & 3,0 \\
& & 1 & 0,4 \\
\hline Toplam & & 236 & 100 \\
\hline
\end{tabular}

Tablo 6 incelendiğinde betimsel desende 93 tezin $(\% 39,4)$, literatür taramasina dayalı desende 87 tezin $(\% 36,9)$, deneysel desende 31 tezin $(\% 12,3)$, içerik analizine dayalı desen ile 9 tezin $(\% 3,8)$, model geliştirme deseninde 7 tezin $(\% 3,0)$, karma desende yapılmış 8 tezin $(\% 3,4)$ ve saha araştırmasına dayalı bir tezin $(\% 0,4)$ olduğu saptanmıştır. Bu sonuca göre literatür taramas1 ve bir durumu saptamaya yönelik betimsel araştırma deseni kullanan tezlerin çoğunlukta olduğu söylenebilir. Analiz sonucunda araştırma deseni ile tezlerin türü karşılaştırıldığında literatür taraması deseninde 60 , betimsel araştırma deseninde 84 yüksek 
lisans tezi olduğu saptanmıştır. Saha araştırması desenindeki bir tezin yüksek lisans programında yapıldığ 1 , betimsel ve deneysel karma desende yapılan 6 tezin doktora, bir tezin sanatta yeterlik programında olduğu, model geliştimeye yönelik 5 doktora tezi, 2 yüksek lisans tezi olduğu ve deneysel desende yapılan tezlerin 22'si doktora programında, 9'u yüksek lisans programında yapılmıştır. Bu sonuçlar doğrultusunda sanatta yeterlik tezlerinin büyük çoğunluğu $(\% 85,7)$ literatür taramasına dayal1, doktora tezleri ise deneysel $(\% 44,5)$, karma $(\% 12,8)$, betimsel $(\% 21,3)$ ve model geliştirme $(\% 10,6)$ desenlerinde yapıldığı görülmektedir.

\subsection{Lisansüstü Tezlerin Araştırma Yöntemi}

Tablo 7. Tezlerin araştırma yöntemine göre dağ 11 ımı

\begin{tabular}{lcc}
\hline Araştırmanın Yöntemi & $\mathrm{f}$ & $\%$ \\
\hline Nicel Yöntem (İstatistiksel analizlerin yapıldığı araştırmalar) & 102 & 43,2 \\
Nitel Yöntem (Gözlem görüşme ve doküman analizine dayalı araştırmalar) & 105 & 44,5 \\
Karma Yöntem (İki ve daha fazla yöntemin birlikte kullanıldığı araştırmalar) & 11 & 4,7 \\
Diğer (Tematik, metodolojik ya da kronolojik değerlendirmelerin yapıldığı derleme & 18 & 7,6 \\
araştırmalar) & & \\
\hline Toplam & 236 & 100 \\
\hline
\end{tabular}

Lisansüstü tezlerin araştırma yöntemlerine göre dağılım incelendiğinde nicel yöntem ile $102(\% 43,2)$, nitel yöntem ile 105 (\%44,5), karma yöntemlerin kullanıldığ $111(4,7)$ ve derleme araştırmaların yapıldığ $18(7,6)$ tezin olduğu saptanmıştır. Bu sonuç nicel ve nitel yöntemlerin benzer düzeyde kullanıldığını göstermektedir. Araştırma yöntemlerinin araştırma desenine göre karşılaştıması yapıldığında derleme araştırmaların tamamının literatür taraması deseninde olduğu, içerik analizi ve saha araştırmalarının tamamı nitel araştırma yöntemiyle yapıldığ saptanmıştır. Nicel yöntemin çoğunlukla betimsel $(\% 65,7)$ ve deneysel $(\% 27,6)$ araştırmalarda kullanıldığı, nitel yöntemin ise literatür taraması $(\% 67,6)$, betimsel $(\% 17,6)$ araştırmalarda kullanıldı̆̆ söylenebilir.

\subsection{Lisansüstü Tezlerde Kullanılan Veri Toplama Araçları}

Tablo 8. Tezlerin veri toplama aracına göre dağılımı

\begin{tabular}{lcc}
\hline Veri Toplama Araçları & $\mathrm{f}$ & $\%$ \\
\hline Gözlem Formu (uygulamaya dönük video destekli, yapılandırılmış) & 35 & 13 \\
Görüşme Formu (yapılandırılmış, yarı yapılandırılmış) & 33 & 12,2 \\
Doküman Analizi (kitap, metot, basılı nota, albüm, fotoğraf vb.) & 95 & 35,2 \\
Anket (görüş belirlemek için açı ve kapalı uçlu sorular) & 69 & 25,6 \\
Test (performansı ölçmek için geliştirilmiş çoktan seçmeli vb. test) & 16 & 5,9 \\
Ölçek (öğrenme stilleri, tutum ölçeği vb.) & 22 & 8,1 \\
\hline Toplam & 270 & 100 \\
\hline
\end{tabular}

Veri toplama aracı dağılımı incelendiğinde, lisansüstü tezlerde kullanılan 6 farklı veri toplama aracı ortaya çıkmış, 236 tezde toplam 270 veri toplama aracı kullanıldığı saptanmıştır. En s1k kullanılan veri toplama araçları doküman analizi $(\% 35,2)$, anket $(\% 25,6)$, gözlem formu (\%13) ve görüşme $(\% 12,2)$ formudur. Ölçek ve test gibi geliştirilmiş, geçerlik güvenirlik yapılmış ölçme araçlarının daha az kullanıldığı görülmektedir. Bunun nedeni alana yönelik performans testlerinin ve geliştirilmiş ölçeklerin az olmasından, diğer alanlarda geliştirilmiş ölçeklerin bu alanda kullanımının uygun olamamasından ve alana özgü ölçek geliştirme çalışmalarının hem eğitim bilimleri hem de istatistik alanlarında uzmanlık istemesinden dolayı araştırmacıların bu çalışmalara yönelmemesinden kaynaklandığı düşünülmektedir. 


\subsection{Lisansüstü Tezlerin Örneklem Grubu}

Tablo 9. Tezlerin Örneklem Grubuna Ait Dağılımı

\begin{tabular}{lcc}
\hline Örneklem Grubu & $\mathrm{f}$ & $\%$ \\
Kitap, metot, nota vb. basılı materyaller & 92 & 36,2 \\
Üniversite öğrencileri & 78 & 30,7 \\
Piyano öğretim elemanları ve piyano öğretmenleri & 48 & 18,9 \\
AGSL öğrencileri & 13 & 5,1 \\
Piyanist, korrepetitör (solist-icracı) & 6 & 2,4 \\
İlköğretim birinci ve ikinci kademe öğrencileri & 3 & 1,2 \\
Okul öncesi öğrencileri & 3 & 1,2 \\
İlköğretim müzik öğretmenleri & 3 & 1,2 \\
Müzik kurumlarındaki yöneticiler & 2 & 0,8 \\
Piyano akordör & 2 & 0,8 \\
Piyano öğretim programı & 1 & 0,4 \\
Yaylı çalgı öğretim elemanları & 1 & 0,4 \\
Dinleyici & 1 & 0,4 \\
Müzik kurumları & 1 & 0,4 \\
\multicolumn{1}{c}{ Toplam } & 1 & 100 \\
\hline
\end{tabular}

Tezlerde yer alan örneklem grubu dağılımı incelendiğinde, \%36,2'sinin kitap, metot, nota vb. materyaller olduğu, \%30,7'sinin üniversitelerin müzik bölümlerindeki (konservatuar, güzel sanatlar, müzik öğretmenliği) öğrenciler olduğu, \%18,9’unun piyano öğretim elemanları ve piyano öğretmenleri olduğu ve \%5,1'inin güzel sanatlar lisesi öğrencileri olduğu görülmektedir. Dağılıma göre kalan yüzdelik kısım ilköğretim, orta öğretim kademesi öğrencileri, piyanistler, korrepetitörler, akordör, öğretim programı, kurumlar ve dinleyicilerdir. $\mathrm{Bu}$ sonuca göre piyano ile ilgili araştırmaların büyük çoğunluğu örneklemini materyal inceleme ve üniversite ile lise bünyesindeki öğretim elemanı ve öğrenciler üzerinde yoğunlaştırdığ 1 söylenebilir.

\subsection{Lisansüstü Tezlerde Kullanılan Veri Analiz Yöntemi}

Tablo 10. Tezlerde kullanılan veri analiz yöntemine göre dağılım

\begin{tabular}{|c|c|c|c|}
\hline \multicolumn{2}{|l|}{ Veri Analiz Yöntemi } & $\mathrm{f}$ & $\%$ \\
\hline \multicolumn{2}{|c|}{ Betimleyici İstatistik Yöntemleri (f, \%, vb.) } & 49 & 13,4 \\
\hline \multicolumn{2}{|c|}{ Yordaicı (İlişkisel) İstatistik Yöntemleri (Korelâsyon, anova, t-testi, vb.) } & 56 & 25,7 \\
\hline \multicolumn{2}{|c|}{ Betimsel Analiz } & 85 & 39,0 \\
\hline \multicolumn{2}{|l|}{ İçerik Analizi } & 16 & 4,4 \\
\hline \multicolumn{2}{|c|}{ İkonografik analiz (görsel sanat eseri analizi) } & 1 & 0,5 \\
\hline \multirow{3}{*}{ Karma Analiz Yöntemleri } & Betimleyici istatistik ve betimsel analiz & 3 & 1,4 \\
\hline & İlişkisel istatistik ve betimsel analiz & 5 & 2,3 \\
\hline & İlişkisel istatistik ve içerik analizi & 3 & 1,4 \\
\hline \multicolumn{2}{|l|}{ Toplam } & 218 & 100 \\
\hline
\end{tabular}

Tezlerde kullanılan veri analiz yöntemleri incelendiğinde, 236 tez içerisinde 218 'inin veri analiz birimi kullandığ 1,18 tezin tematik, metodolojik ya da kronolojik değerlendirmelerin yapıldığ 1 derleme araştırmalar olduğu saptanmıştır. Dağılıma göre tezlerin \%39'unun nitel araştırma veri analizi yöntemlerinden betimsel analizi, \%4,4'ünün içerik analizini ve \%0,5'inin ikonografik analizi kullandığ 1 görülmektedir. Nicel araştırma veri analiz yöntemlerinden betimleyici istatistik kullanan araştırmalar \%13,4, ilişkisel istatistik yöntemleri kullanan tezler $\% 25,7$ ve karma analiz yöntemi kullanan tezler ise $\% 5,1$ 'dir. Bu sonuca göre nitel ve nicel veri analiz yöntemleri araştırma yöntemine paralel olarak benzer oranlarda dağ 11 ım göstermektedir.

\subsection{Lisansüstü Tezlerdeki Ortalama Katılımcı Sayısı}

Tablo 11. Lisansüstü tezlerdeki katılımcı sayısı

\begin{tabular}{cccccc}
\hline \multirow{2}{*}{ Katılımc Sayıs1 } & $\mathrm{n}$ & Minimum & Maksimum & Ortalama & Ss \\
& 203 & 1 & 1142 & 65,70 & 137,41 \\
\hline
\end{tabular}


Lisansüstü tezlerdeki örneklemde yer alan katılımcı sayıları incelendiğinde 203 araştırmada minimum 1 kişi, maksimum 1142 kişi, ortalama kişi sayısının 65 olduğu görülmektedir. $\mathrm{Bu}$ sonuç özellikle betimsel araştırmalarda her ne kadar örneklemin sayısal azlığını ortaya çıkarsa da, müzik alanına yönelik evren-örneklem, alana özel araştırmalar yapılma durumu ve hatta deneysel araştırmalar düşünüldüğünde bu dağılımının ortalama düzeyde olduğu söylenebilir.

\subsection{Deneysel Araştırmalarda Uygulama Süresi}

Tablo 12. Deneysel araştırmalardaki uygulama süresi

\begin{tabular}{|c|c|c|c|c|c|c|c|}
\hline \multirow[b]{2}{*}{ Uygulama Süresi } & & & $\mathrm{n}$ & Minimum & Maksimum & Ortalama & ss \\
\hline & $\begin{array}{l}\text { Deneysel Desen } \\
\text { Karma Desen }\end{array}$ & $\begin{array}{l}31 \\
7\end{array}$ & 38 & 1 & 30 & 7,31 & 5,61 \\
\hline
\end{tabular}

Deneysel desende uygulama yapan araştırmalardaki uygulama süresi (uygulama sayısı) incelendiğinde, deneysel çalışmaların 1 ile 30 uygulama arasında yapıldığ 1 ve ortalama uygulama sayısının 7 uygulama olduğu görülmektedir. $\mathrm{Bu}$ sonuç deneysel çalışmalardaki uygulamaların daha uzun uygulama sürecine yayılması gerektiğini göstermektedir.

\subsection{Deneysel Araştırmalardaki Katılımcı Sayısı}

Tablo 13. Deneysel araştırmalardaki katılımcı sayısı

\begin{tabular}{lllccccc}
\hline Katılımc1 & Deneysel Desen & 31 & n & Minimum & Maksimum & Ortalama & ss \\
Sayıs1 & Karma Desen & 7 & 38 & 10 & 66 & 22,42 & 11,65 \\
\hline
\end{tabular}

Deneysel desen uygulayan tezlerdeki katılımcı sayıları incelendiğinde 10 ile 66 kişi arasında değişmekte olduğu ve ortalama katılımcı sayısının 22 olduğu görülmektedir. Bu sonuca göre deneysel desendeki ortalama katılımc sayılarının uygulama örneklem alanı düşünüldüğünde sayısal olarak normal düzeyde olduğu söylenebilir.

\subsection{Deneysel Araştırmalardaki Uygulama Grubu}

Tablo 14. Deneysel araștırmalardaki uygulama grubunun dağılımı

\begin{tabular}{lcc}
\hline Uygulama Yapılan Grup & $\mathrm{F}$ & $\%$ \\
\hline Yükseköğretim kurumlarında müzik eğitimi alan öğrenciler & 30 & 78,9 \\
AGSL kurumlarında müzik eğitimi alan öğrenciler & 3 & 7,9 \\
Okulöncesi (anaokulu) öğrencileri & 1 & 2,6 \\
İlköğretim birinci ve ikinci kademe öğrenciler & 4 & 10,5 \\
\hline \multicolumn{1}{c}{ Toplam } & 38 & 100 \\
\hline
\end{tabular}

Deneysel araştırmalardaki uygulama grubu dağılımı incelendiğinde \%78,9 ile büyük çoğunluğunun üniversitelerdeki müzik bölümlerinde eğitim alan öğrenciler olduğu, kalan yüzdelik dilimde ise \%10,5'inin ilköğretim kademesi öğrencileri, \%7,9'unun güzel sanatlar lisesi müzik öğrencileri ve \%2,6'sının okulöncesi öğrencileri olduğu ortaya çıkmıştır. Uygulama alanı dağılımında ortaya çıkan bu sonucun nedeni olarak, üniversitelerde piyanonun eğitim aracı olarak her zaman kullanılması, piyano alanında örneklem yoğunluğunun üniversitelerde olması, uygulamaların bu kurumlarda kolaylıkla yapılmasından kaynaklandığı düşünülmektedir. Buna ek olarak üniversitelerdeki deneysel araştırma uygulamalarının diğer milli eğitim kurumlarına oranla gerekli izin ve uygulama kolaylığı bakımından daha hızlı ve rahat yapılabilmesine bağlanmaktadır. 


\subsection{Deneysel Araştırmalardaki Uygulamanın Yapıldığı Dersler}

Tablo 15. Deneysel araştırmalardaki uygulama derslerinin dağılımı

\begin{tabular}{lcc}
\hline Uygulama Yapılan Ders & $\mathrm{f}$ & $\%$ \\
\hline Müzik eğitimi veren ilköğretim, lise ve üniversitelerdeki piyano dersi & 32 & 84,2 \\
Okulöncesi kurumlarda verilen müzik dersi & 1 & 2,6 \\
Müzik eğitimi veren yüksek öğretim kurumlarındaki eşlik dersi & 2 & 5,3 \\
İköğretim kurumlarındaki müzik dersi & 3 & 7,9 \\
\hline Toplam & 38 & 100 \\
\hline
\end{tabular}

Tablo 15 incelendiğinde piyano konu alanı ile paralel olarak uygulama derslerinin $\% 84,2$ ile büyük çoğunluğu piyano dersinde, \%7,9'u ilköğretim müzik dersinde, \%5,3’ü eşlik dersinde ve \%2,6's1 okulöncesi müzik dersinde yapılmıştır.

\subsection{Deneysel Araştırmalardaki Desen}

Tablo 16. Deneysel araştırmalardaki deneysel desen dağılımı

\begin{tabular}{llcc}
\hline Desen & & $f$ & $\%$ \\
\hline \multirow{2}{*}{ Gerçek Deneme Modelleri } & Ön-Son Test Kontrol Gruplu Model & 29 & 76,3 \\
Deneme Öncesi Modeller & Son Test Kontrol Gruplu Model & 4 & 10,5 \\
Yarı Deneme Modelleri & Tek Grup Ön-Son Test Model & 3 & 7,9 \\
& Ön-Son Test Eşitlenmemiş Kontrol Gruplu Model & 2 & 5,3 \\
\hline Toplam & & 38 & 100 \\
\hline
\end{tabular}

Tablo 16'daki deneysel desen dağılımı incelendiğinde \%76,3'ünün gerçek deneme modellerinden ön test son test kontrol gruplu modelde, \%10,5'inin son test kontrol gruplu modelde, \%7,9'unun deneme öncesi modelleden tek grup ön test son test modelde ve \%5,3'ünün yarı deneme modellerinden ön test son test eşitlenmemiş kontrol gruplu modelde yapıldığı ortaya çıkmıştır. Bu sonuca göre yapılan deneysel araştırmaların büyük çoğunluğunun gerçek deneme modeli ile gerçekleştiği görülmektedir.

\subsection{Lisansüstü Tezlerin Araştırma Konusu}

Tablo 17. Lisansüstü tezlerin araştırma konusuna göre dağılımı

\begin{tabular}{|c|c|c|}
\hline Konular & $\mathrm{f}$ & $\%$ \\
\hline Piyano eserlerinin (sonat, konçerto, füg vb.) form, teknik ve müzikal açıdan incelenmesi/analizi & 80 & 33,9 \\
\hline $\begin{array}{l}\text { Mesleki müzik eğitimi veren kurumlarda ve AGSL'de piyano eğitiminin genel durum } \\
\text { değerlendirmesi }\end{array}$ & 26 & 11,0 \\
\hline $\begin{array}{l}\text { Eğitim kuramları ve modellerinin (bilgiyi işleme, çevrilmiş öğrenme, problem çözmeye dayalı } \\
\text { öğrenme, öğrenme stratejileri, öğrenme stilleri, öz düzenlemeli öğrenme modelleri, mikro öğretim ve } \\
\text { analitik ezberleme yaklaşımları) piyano eğitiminde öğrencinin performansına, tutumuna ve/veya } \\
\text { başarısına etkisi }\end{array}$ & 25 & 10,6 \\
\hline $\begin{array}{l}\text { Çağdaş Türk piyano eserlerinin sınıflaması, Türk halk türkülerinin ve Türk müziği kaynaklı eserlerin } \\
\text { piyano eğitiminde kullanılması }\end{array}$ & 17 & 7,2 \\
\hline Piyano tekniğine yönelik kazanım, başarı ve durum değerlendirmesi, etüt egzersiz çalışmaları & 15 & 6,4 \\
\hline Piyano için yazılmış başlangıç metotlarının incelenmesi & 11 & 4,7 \\
\hline $\begin{array}{l}\text { Piyanonun eşlik çalgısı olarak kullanımı, işlevsel ve doğaçlama eşlik becerisinin önemi ve } \\
\text { geliştirilmesi }\end{array}$ & 10 & 4,3 \\
\hline $\begin{array}{l}\text { Okulöncesi ve ilköğretim dönemde piyano eğitiminin önemi ve kullanılan özel öğretim yöntem ve } \\
\text { materyaller }\end{array}$ & 7 & 3,0 \\
\hline Piyanoda armoni, kontrpuan, poliritim, polifoni ilişkisi ve çalma becerisine etkisi & 6 & 2,6 \\
\hline Piyano eğitiminde pedal kullanımına yönelik araştırmalar & 5 & 2,1 \\
\hline Piyanoda ekoller ve pedagojik yaklaşımlar & 4 & 1,7 \\
\hline de caz müziği ve armonisinin kullanımı & 4 & 1,7 \\
\hline lişma tekniklerinin çalm & 4 & 1,7 \\
\hline ölçme ve buna yönelik ölçek geliştirme çalışması & 3 & 1,3 \\
\hline bilgisayar, video, müzik yazılım programlarının kullanımı & 3 & 1,3 \\
\hline Barok dönem piyano müziği ve süslemelerin çalışma teknikleri & 3 & 1,3 \\
\hline Piyano dersine yönelik model geliştirme çalışmaları & 2 & 0,8 \\
\hline Piyano eğitiminde karşılaşılan bedensel rahatsızlıklar ve alınabilecek önlemler & 2 & 0,8 \\
\hline Piyanonun bakım, onarım ve akorduna yönelik çalışmalar & 2 & 0,8 \\
\hline Piyano eserinin askeri bandoya uygun orkestrasyon çalışması & 2 & 0,8 \\
\hline
\end{tabular}




\begin{tabular}{lcc}
\hline Türkiye ve Azerbaycan piyano eğitim programlarının karşılaştırması & 1 & 0,4 \\
Mozart piyano koçertolarına çerçeve kadans modeli oluşturma çalışması & 1 & 0,4 \\
Halkevlerinde yürütülen piyano eğitimi çalışmaları & 1 & 0,4 \\
Osmanlı döneminde yazılmış piyano eserlerinin incelenmesi & 1 & 0,4 \\
Piyano eşlikli performanslarda eşlikçinin deneyim, beceri ve uyum düzeyi & 1 & 0,4 \\
Toplam & 236 & 100 \\
\hline
\end{tabular}

Lisansüstü tezlerin konularına göre dağılımı 25 farklı kategoride sınıflanmıştır. Buna göre piyano ile ilgili 80 araştırma $(\% 33,9)$ piyano eserlerinin form, teknik ve müzikal açıdan analizine dayanmaktadır. Mesleki müzik eğitimi veren kurumlarda ve güzel sanatlar liselerinde piyano eğitiminin genel durum değerlendirmesini yapan $26(\% 11,0)$ araştırma, eğitim kuramları ve modellerinin piyano eğitiminde öğrenci başarısına etkisini araştıran $25(\% 10,6)$ çalışma, çağdaş Türk piyano eserlerinin sınıflaması, Türk halk türkülerinin ve Türk müziği kaynaklı eserlerin piyano eğitiminde kullanılması üzerine $17(\% 7,2)$ araştırma, piyano tekniğine yönelik kazanım, başarı ve durum değerlendirmesi, etüt egzersiz çalışmalarını içeren $15(\% 6,4)$ araştırma, piyano için yazılmış başlangıç metotlarını inceleyen $11(\% 4,7)$ ve piyanonun eşlik çalgısı olarak kullanımı, işlevsel ve doğaçlama eşlik becerisinin önemi ve geliştirilmesi üzerine $10(\% 4,3)$ araştırma bulunmaktadır.

\section{Sonuç Tartışma ve Öneriler}

Piyanoya yönelik lisansüstü tezlerin sistematik olarak incelenmesi amacıyla yapılan bu araştırmada 236 yüksek lisans, doktora ve sanatta yeterlik tezi incelenerek kodlanmış ve tezler araştırma yılı, araştırmacının cinsiyeti, üniversite ve enstitülere göre dağılımı, araştırmanın türü, araştırmanın yöntemi ve deseni, konusu, örneklem grubu, veri toplama aracı ve veri analiz yöntemi, katılımcı sayısı, deneysel araştırmalarda uygulama yapılan grup, ders, uygulama süresi, deneysel uygulama grubu sayısı ve veri analiz yöntemine göre tablolaştırılarak yorumlanmıştır. Araştırma sonucunda 1995-2017 yılları arasında yapılan 236 tezin üçte ikisinin 2004-2007 yılları arasında yapıldığı ve araştırmaların 2010 yılına kadar niceliksel olarak artış gösterirken 2013 yılından itibaren ise miktarın giderek azaldığı söylenebilir. Piyanonun çalg1 olarak başlı başına hem eğitsel, pedagojik hem de teknik ve müzikal boyutta geniş bir araştırma alanına sahip olduğu düşünüldüğünde, araştırmaların niceliksel olarak artması sevindiricidir. Bu nedenle piyano ile ilgili araştırmaların nicelik ve nitelik olarak artması bu alana büyük katkı sağlayacaktır. Ayrıca içeriğe alınamayan 1987-1994 yılı arası araştırmaların da taranarak arşivlenmesiyle, hem alana kazandırılacak hem de araştımacılara farklı literatür sağlayacak ve yeni araştırma alanı açacağından, bundan sonra yapılacak araştırmalara önerilmektedir.

Lisansüstü tezlerin 33 üniversitede 5 farklı enstitüde yapıldığı, ilk siralarda yer alan üniversitelerin çoğunluğunun (Gazi Üniversitesi 1987, Marmara Üniversitesi 1987, İstanbul Üniversitesi 1992, İnönü Üniversitesi 1993, Selçuk Üniversitesi 1996, Hacettepe Üniversitesi 1996, Mimar Sinan Üniversitesi 1996, Dokuz Eylül Üniversitesi 1997) ülkemizde müzik alanına yönelik (konservatuar, müzik eğitimi vb.) açılan lisansüstü bölümlerin ilk örnekleri olduğu bilinmektedir. Farklı branşlara yönelik (viyola, viyolonsel, keman) yapılan diğer lisansüstü tez araştırmalarda da (Sonsel, 2018; Orhan, 2012; Tebiş ve Okay, 2013) benzer şekilde Gazi, Dokuz Eylül, Mimar Sinan, İstanbul Üniversiteleri ilk sirada gelmektedir. Analiz sonucunda en fazla lisansüstü tezin Gazi Üniversitesinde olması, tarihsel olarak ülkemizde açılan ilk müzik eğitimi kurumu olması nedeniyle doğal bir sonuçtur. Cumhuriyet tarihimizde Ankara'da 'müzik öğretmeni' yetiştirmek amacıyla 1924 yılında açılan Musiki Muallim Mektebi, orta öğretime öğretmen yetiştirmeyi ve çoksesli müziği eğitime yerleştirmeyi amaçlıyordu. Bu kurum 1936 yılında yeniden yapılandırılarak Gazi Eğitim Enstitüsü'ne bağlandı. Araştırma sonucunda tezlerin sosyal bilimler ile eğitim bilimleri enstitülerinde ağırlıklı olarak gerçekleştiği görülmektedir. Daha önceleri fen bilimleri enstitüsünde olan müzik eğitimi veren kurumların, 2001 yılından itibaren eğitim bilimleri, sosyal bilimler ve güzel sanatlar enstitüsüne bağlanması nedeniyle ortaya çıkan sonuç beklenen bir durumdur. 
Piyano ile ilgili tezlerin yarıdan fazlasının yüksek lisans araştırması olduğu, sanatta yeterlik ve doktora programlarında bu alana yönelik daha az sayıda tez yapıldığı ve yüksek lisans tezi bitiren araştırmacıların ortalama üçte birinin doktora ve sanatta yeterlik programına devam ettiği görülmektedir. Diğer araştırmalarda (Ataman, 2009; Çeşit, 2015; Sonsel, 2018; Orhan, 2012) benzer şekilde yüksek lisans tezlerinin daha fazla olduğu sonucuna ulaşmıştır. Sonsel (2018) incelediği tezlerde büyük çoğunluğun yüksek lisans programı olmasını, birçok üniversitenin doktora programının olmamasına veya yeni yeni açılıyor olmasına bağlamıştır. Üniversitelere göre 31 üniversitenin yüksek lisans, 12'sinin doktora ve 8 'inin sanatta yeterlik programı yürüttüğü saptanmıştır. Her üç programdan da lisansüstü tez türü olan sadece iki üniversite (Dokuz Eylül ve İstanbul Üniversitesi) bulunmaktadır. Bunun nedeni bu üniversitelerde birden fazla müzik alanına yönelik bölüm (müzik bilimi, müzikoloji, konservatuar, müzik eğitimi vb.) bulunduğu içindir. Bu sonuçlar doğrultusunda doktora ve sanatta yeterlik düzeyinde yapılacak araştırmaların artması ve bunun için öncelikle üniversitelerde doktora ve sanatta yeterlik programlarının açılması önerilmektedir.

Lisansüstü araştırmaların cinsiyete göre dağ 1 lımı sonucunda yüksek lisans ve sanatta yeterlik tezlerinde kadın araştırmacıların ağırlıkta olduğu, doktora programında ise neredeyse yarı yarıya eşitlendiği söylenebilir. Bu sonuç kadınların yüksek lisans programından sonra akademik eğitimine devam etmede sanatta yeterlik programını daha fazla tercih ettiğini ya da doktora programına daha az istekli olduğunu düşündürmektedir. Bayların ise sayısal olarak az olsa da akademik eğitim sürecinde daha istikrarlı olduğu söylenebilir.

Piyano ile ilgili tezlerin yarıdan fazlası bir durumu saptamaya yönelik betimsel araştırma ve literatür taramasına dayalı desende, tezlerin türüne göre karşılaştırıldığında ise sanatta yeterlik tezlerinin büyük çoğunluğu literatür taramasına dayalı, yüksek lisans tezleri ise betimsel ve literatür taramasına dayalı desende yapılmıştır. Doktora tezleri ise ağılıklı olarak deneysel desen olmak üzere, model geliştirme ve karma desende yapılmıştır. Lisansüstü tezlerin araştırma yöntemleri incelendiğinde nicel ve nitel araştırma yöntemlerinin birbirine yakın düzeyde kullanıldığı görülmektedir. Tezlerin yöntemi ve deseni karşılaştırıldığında nicel yöntemin çoğunlukla betimsel desenli araştırmalarda, nitel yöntemin ise çoğunlukla literatür taramasına dayalı araştırmalarda kullanıldığı belirlenmiştir. Bunula birlikte derleme çalışmaların tamamının literatür taramasına dayalı, içerik analizi ve saha araştırmalarının ise tamamı nitel araştırma yöntemiyle yapılmıştır. Bu sonuç tezlerin araştırma yöntemi ve deseninin birbiriyle tutarlı bir ilişkide olduğunu göstermektedir. Yüksek lisans programından sonra doktora programı için seçilen deneysel, model geliştirme ve karma yöntemler uygulamaya dönük, uzun soluklu ve araştırmacı deneyimi isteyen desenlerdir. Bu nedenle doktora programında tercih edilmesi beklenen ve sevindirici bir durumdur. Sanatta yeterlik çalışmalarının, diğer programlardan farklı olarak "müzik ve sahne sanatlarında, özgün bir sanat eserinin ortaya konulmasını" amaçladığından yapısı itibari ile literatür taramasına dayalı araştırmalara daha uygun program gibi görünse de, eylem araştırması, olgubilim ya da kültür araştırması gibi farklı nitel araştırma yöntemlerinin kullanılarak alana katkı sağlanabilir.

Tezlerde veri toplama aracı olarak, kitap, metot, basılı nota, albüm gibi doküman analizi, bir konu üzerine görüş almak için kullanılan anket ve görüşme formu ile piyanoda daha çok performansı ölçmede kullanılan gözlem formu kullanılmıştır. Benzer şekilde Arı, Armutlu, Tosunoğlu ve Toy (2009) araştırması sonucunda tezlerin büyük çoğunluğunda anket ve görüşme veri toplama biçiminin tercih edildiğini saptamıştır. "Sosyal bilimler alanında araştırma öznesi insan olduğu için araştırma deseni olarak alan araştırmalarının, veri toplama biçimi olarak da anketin en fazla kullanılan teknik olması düşündürücü olmamaktadır." (Ar1 ve diğerleri, 2009, s.33). Ölçek ve test gibi geliştirilmiş, geçerlik güvenirlik yapılmış ölçme araçlarının daha az kullanıldığ1 görülmektedir. Bunun nedeni alana yönelik performans testlerinin ve geliştirilmiş ölçeklerin az olmasından, diğer alanlarda geliştirilmiş ölçeklerin bu alanda kullanımının uygun olamamasından ve alana özgü ölçek geliştirme çalışmalarının hem eğitim bilimleri hem de istatistik alanlarında uzmanlık istemesinden dolayı araştırmacıların bu çalışmalara 
yönelmemesinden kaynaklandığı düşünülmektedir. Lisansüstü tezlerin veri analiz yöntemleri incelendiğinde, 236 tez içerisinde 218'inin veri analiz birimi kullandığ 1 , 18 tezin tematik, metodolojik ya da kronolojik değerlendirmelerin yapıldığı derleme araştırmalar olduğu, nitel araştırma veri analizi yöntemlerinden betimsel analizin, nicel araştırma veri analiz yöntemlerinden ise ilişkisel istatistik yöntemlerin daha çok kullanıldı̆̆ görülmektedir. Genel olarak nitel ve nicel veri analiz yöntemlerinin, araştırma yöntemine paralel olarak benzer oranlarda dağ 1 lım gösterdiği söylenebilir. Sözbilir, Güler ve Çiltaş’a göre (2012, s.573) tek veri analiz yöntemi kullanılarak araştırılan konu üzerinde tek bir değişkenin etkisinin incelenmesi, yapılan çalışmaların hem geçerliğini hem de güvenirliğini tehdit eden bir husus olarak karşımıza çıkartır. Bu nedenle araştırmalardaki yöntemin, desenin, veri toplama araçlarının, veri analiz yönteminin dikkatle tasarlanması önemli görülmektedir.

Örneklem grubu seçiminde piyano ile ilgili araştırmaların büyük çoğunluğu örneklemini materyal inceleme, bunun yanında üniversite ve lise bünyesindeki müzik bölümlerindeki (konservatuar, güzel sanatlar, müzik öğretmenliği) öğretim elemanı ve öğrenciler üzerinde yoğunlaştırmıştır. Diğer örneklem grupları ise ilköğretim, orta öğretim kademesi öğrencileri, piyanistler, korrepetitörler, akordör, öğretim programı, kurumlar ve dinleyicilerdir. Lisansüstü tezlerdeki katılımcı sayısı incelendiğinde 203 araştırmada örneklemdeki katılımcı sayısı ortalamasının 65 olduğu ve müzik alanı ve bu alana ilişkin evren düşünüldüğünde, bu sayı dağılımının ortalama düzeyde olduğu düşünülmektedir.

Deneysel araştırmalarda ortalama uygulama süresi 7, ortalama katılımcı sayısı ise 22 olarak saptanmıştır. Piyano ile ilgili deneysel araştırmaların performans uygulamalarına dayalı olduğu düşünüldüğünde ortalama sürenin daha uzun sürece yayılarak artırılması, daha verimli sonuçlar almak için gerekli görülmektedir. Bununla birlikte ortalama katılımcı sayısının uygulama örneklem alanı düşünüldüğünde sayısal olarak az olmadığı söylenebilir. Deneysel araştırmalardaki uygulama grubu dağılımı çoğunlukla üniversitelerdeki müzik bölümlerinde eğitim alan öğrencilerden ve piyano dersinden oluşmaktadır. Uygulama alanı dağılımında ortaya çıan bu sonucun nedeni olarak, üniversitelerde piyanonun eğitim aracı olarak her zaman kullanılması, piyano alanında örneklem yoğunluğunun üniversitelerde olması, uygulamaların bu kurumlarda kolaylıkla yapılmasından kaynaklandığı düşünülmektedir. Buna ek olarak üniversitelerdeki deneysel araştırma uygulamalarının diğer milli eğitim kurumlarına oranla gerekli izin ve uygulama kolaylığı bakımından daha hızlı ve rahat yapılabilmesine bağlanmaktadır. Deneysel araştırmalardaki desen incelendiğinde, büyük çoğunluğunun gerçek deneme modellerinden ön test son test kontrol gruplu modelde gerçekleştiği görülmektedir. Karasar'ın (2000, s.97) gerçek deneme modelleriyle yapılanların bilimsel değeri en yüksek denemeler olduğu görüşünden hareketle, araştırmadaki deneysel modellerin büyük çoğunluğunun gerçek deneme modelinde yapılması, gelecekte yapılacak yeni araştırmalara daha net sonuçlar vermesi açısından önem kazanmaktadır.

Tezlerin konu dağılımı 25 farklı kategoride sınıflanmıştır ve üçte birinin piyano eserlerinin form, teknik ve müzikal açıdan analizine dayanmaktadır. Sonrasında yüzdelik sıralama ile konular, mesleki müzik eğitimi veren kurumlarda ve güzel sanatlar liselerinde piyano eğitiminin genel durum değerlendirmesi, araştırma, eğitim kuramları ve modellerinin piyano eğitiminde öğrenci başarısına etkisi, çağdaş Türk piyano eserlerinin sınıflaması, Türk halk türkülerinin ve Türk müziği kaynaklı eserlerin piyano eğitiminde kullanılması, piyano tekniğine yönelik kazanım, başarı ve durum değerlendirmesi ile etüt egzersiz çalışmaları ve piyano için yazılmış başlangıç metotlarının incelenmesi şeklindedir. Bu araştırma sonucunda hiç de azımsanmayacak düzeyde konu içeriklerinin varolduğu, farklı desenlerle, yöntemlerle, veri toplama araçları ve analiz yöntemleriyle araştırmaların olduğunu söylemek mümkündür. Üniversitelerde yeni açılan fakülteler ve enstitüler arttıkça, bünyesinde lisansüstü programlara da yer verecektir. Lisanüstü araştırmalar hem alana katkı sağlamakta hem de araştırmacıları bilimsel yönden geliştirmektedir. Müzik disiplini içerisinde hem alana katkı sağlaması hem de 
bilimsel yenilik katması açısından, piyano alanına yönelik araştırmaların da nicelik ve nitelik olarak artması önerilmektedir.

\section{Kaynakça}

Alyörük, G. (2016). Türkiye'de gitar alanında yapılan lisansüstü tezler: bir bibliyografya çalışması. Balikesir University Journal Of Social Sciences Institute, 19 (35).

Arı, G. Armutlu, C. Tosunoğlu, N. ve Toy, B. (2009). Nicel araştırmalarda metodoloji sorunları:yüksek lisans tezleri üzerine bir araştırma. Ankara Üniversitesi SBF Dergisi, 64 (04), 16-37. DOİ:10.1501/Sbfder_0000002143

Ataman, Ö. G. (2009). Ülkemizde flüt ve flüt eğitimi alanlarında yapılan lisansüstü tezler. Kastamonu Ë̆itim Dergisi, 17(1) 341-352.

Berki, T. (1997). Mozart'ın piyano konçertolarına iliş̧in bir çerçeve kadans modeli. (Yayımlanmamış doktora tezi). Gazi Üniversitesi Fen Bilimleri Enstitüsü, Ankara.

Bıkmaz, F. H. Aksoy, E. Tatar, Ö. ve Altınyüzük, C. A. (2013). Eğitim programları ve öğretim alanında yapılan doktora tezlerine ait içerik çözümlemesi (1974-2009). Eğitim ve Bilim, 38(168).

Bucak, S. (1995). Haydn piyano sonatları. (Yayımlanmamış sanatta yeterlik tezi). Mimar Sinan Üniversitesi Sosyal Bilimler Enstitüsü, İstanbul.

Büyüköztürk, Ş. Kılıç Çakmak, E. Akgün, Ö. E. Karadeniz, Ş. ve Demirel, F. (2008). Bilimsel araştırma yöntemleri. Ankara: Pegem A Yayıncılık.

Çeşit, C. (2015). Türkiye'de viyola üzerine yapılan lisansüstü tezlerin incelenmesi. The Journal of Academic Social Science Studies, 38, 445-462. Doi:http://dx.doi.org/10.9761/JASSS3035

Çevik, D. B. (2002). Claude Debussy ve piyano eğitimi. (Yayımlanmamış yüksek lisans tezi). Dokuz Eylül Üniversitesi Eğitim Bilimleri Enstitüsü, İzmir.

Çiltaş, A. Güler, G. ve Sözbilir, M. (2012). Türkiye'de matematik eğitimi araştırmaları: bir içerik analizi çalışması. Kuram ve Uygulamada Eğitim Bilimleri, 12(1), 565-580.

Demirbatır, R. E. (2001). Müzik alanı yüksek lisans, doktora ve sanatta yeterlik tez bibliyografyası. Uludağ Üniversitesi Eğitim Fakültesi Dergisi, 14(1), 123-141.

Erdal, G. G. (2005). Koordinatif-kondisyonel motorik özelliklerin geliştirilmesine yönelik antrenmanların piyano çalma performansina olan etkilerinin incelenmesi ve piyano tekniğinin hareket analizi. (Yayımlanmamış doktora tezi). Kocaeli Üniversitesi Sağlık Bilimleri Enstitüsü, Kocaeli.

Gedikli, A. S. (2006). Debussy prelüd'lerin 20. yüzyll piyano müziği'ndeki yeri ve önemi. (Yayımlanmamış sanatta yeterlik tezi). Dokuz Eylül Üniversitesi Güzel Sanatlar Enstitüsü, İzmir.

Kalyoncu, N. (1996). Anadolu güzel sanatlar liseleri müzik bölümlerinde piyano öğretim programlarının hedeflerine ulaşma durumu. (Yayımlanmamış yüksek lisans tezi). Abant İzzet Baysal Üniversitesi, Sosyal Bilimler Enstitüsü, Bolu.

Karakaya, İ. (2014). Bilimsel Araştırma Yöntemleri. Tanrıöğen, A. (Ed.) Bilimsel Araştırma Yöntemleri. Ankara: Anı Yayıncılık.

Karasar, N. (2000) Bilimsel Araştırma Yöntemi. Ankara: Nobel Yayınları.

Karataş, K. O. ve Şengül, C. (2018). Türkiye'de mesleki müzik eğitimi veren kurumlardaki piyano ders içeriklerinin incelenmesi. Journal of Graduate School of Social Sciences, 22(1). 
Karkın, A. M. (2011). Müzik bilimleri alanında yapılan lisansüstü tezlerin incelenmesi. İnönü Üniversitesi Sanat ve Tasarm Dergisi, 1(2).

Miles, M. B. ve Huberman, A. M. (1994). Qualitative data analysis (2nd ed.) Thousand Oaks, CA: Sage

Orhan, Ş. Y. (2012). Türkiye'de viyolonsel alanında yapılmış yüksek lisans, doktora ve sanatta yeterlilik tezleri. Kastamonu Eğitim Dergisi, 20(2), 701-716.

Önal, E. (2005). Henry Cowell'ın piyanodan farklı tını elde etme teknikleri. (Yayımlanmamış sanatta yeterlik tezi). Bilkent Üniversitesi Müzik ve Sahne Sanatları Enstitüsü, Ankara.

Öztutgan, Z. (2016). Türkiye'de gitar alanında yapılan lisansüstü tezlerin analizi ve değerlendirilmesi. Yüzüncü Yıl Üniversitesi Eğitim Fakültesi Dergisi, 13(1), 684-708.

Öztürk, F. G. ve Dinç, H. (2016) Lisansüstü eğitim alan müzik öğretmenlerinin eğitimleri sürecinde karşılaştıkları sorunlar. İdil Dergisi, 5(21). DOI: 10.7816/idil-05-21-15

Saban, A. (2009). Çoklu zekâ kuramı ile ilgili türkçe çalışmaların içerik analizi. Kuram ve Uygulamada Ë̆itim Bilimleri, 9(2), 833-876.

Sonsel, Ö. B. (2018). Türkiye'de viyola alanında yazılmış lisansüstü tezlerin incelenmesi. Mehmet Akif Ersoy Üniversitesi Eğitim Fakültesi Dergisi, (47), 340-359.

Soycan, M. ve Babacan, E. (2019). Müziksel işitme, okuma ve yazma ile ilgili geliştirilmiş ölçme araçlarının incelenmesi: içerik analizi çalışması. Elektronik Sosyal Bilimler Dergisi, 18 (69), 343-353. DOI:10.17755/esosder.409006

Tebiş, C. ve Okay, H. H. (2013). Türkiye'de müzik sanatı ve eğitiminde keman ve viyola konulu lisansüstü tezlerin konu ve yöntem olarak incelenmesi. International Journal of New Trends in Arts, Sports \& Science Education (IJTASE) 2(2)

Uçan, A. (1996). İnsan ve müzik insan ve sanat eğitimi. Ankara: Müzik Ansiklopedisi Yayınları.

Ünal, Z. O. (2008). Probleme dayalı öğrenme modelinin piyano ve öğretimi alanındaki yeterlilik algısına etkisi. (Yayımlanmamış doktora tezi). Marmara Üniversitesi Fen Bilimleri Enstitüsü, İstanbul.

Yıldırım, A. ve Şimşek, H. (2000). Sosyal bilimlerde nitel araştırma yöntemleri, Ankara: Seçkin Yayınlar1.

YÖK. (2007). Eğitim fakültesi öğretmen yetiştirme ders programları. Ankara: Yükseköğretim Kurulu Yayını.

Yönetken, H. B. (1996). Okulda çalgı sorunu ve çalgısal müzik etkinlikleri. A. Say (Ed.). Müzik Öğretimi (69-70). Ankara: Müzik Ansiklopedisi Yayınları.

Zeybek, A. (2013). Keman ve piyano çalan müzisyenlerde gövde stabilite ve enduransının ağrı ve yorgunluk üzerine etkisi. (Yayımlanmamış yüksek lisans tezi). Hacettepe Üniversitesi Sağlık Bilimleri Enstitüsü, Ankara.

\section{Ek 1.}

*Acar, E. (2016). Askerî bando orkestralama tekniklerinin incelenmesi ve Frederic Chopin'in l'inci piyano konçertosunun l'inci bölümünün askerî bandoya transkripsiyonu. (Yayımlanmamış yüksek lisans tezi). Cumhuriyet Üniversitesi Sosyal Bilimler Enstitüsü, Erzurum.

*Acemoğlu, Y. (2006). Kuzey Kıbrıs Türk Cumhuriyeti ve Türkiye Cumhuriyeti'ndeki güzel sanatlar liselerinde okutulan piyano dersi öğretim programlarının karşılaştırllması. (Yayımlanmamış yüksek lisans tezi). Uludağ Üniversitesi Sosyal Bilimler Enstitüsü, Bursa. 
*Akcan Ünsal, A. S. (2011). Piyano eğitimindeki motivasyon durumunun öğretim elemanı ve ögrenci açısından incelenmesi. (Yayımlanmamış yüksek lisans tezi). Selçuk Üniversitesi Eğitim Bilimleri Enstitüsü, Konya.

*Akkuzu, O. (2012). Piyano eğitiminde pedal kullanmada oluşan sorunlar ve müzik dönemlerinde kullanılan farklı stillerdeki pedal teknikleri. (Yayımlanmamış yüksek lisans tezi). Atatürk Üniversitesi Sosyal Bilimler Enstitüsü, Erzurum.

*Akpınar, U. (2009). "Suzuki Piano School Volume I” okul öncesi dönem piyano eğitimine başlangıç metodunun hedef ve hedef davranışlar açısından incelenmesi. (Yayımlanmamış yüksek lisans tezi). Gazi Üniversitesi Eğitim Bilimleri Enstitüsü, Ankara.

*Aktuğ, E. (2002). Resim-müzik ilişkisinin 19. ve 20. yüzyll piyano müziğine yansıması ve Mussorgsky'nin “Bir Sergiden Resimler"i üzerine ikonografik tanımlama. (Yayımlanmamış yüksek lisans tezi). Dokuz Eylül Üniversitesi Sosyal Bilimler Enstitüsü, İzmir.

*Akyıldız, O. (2007). Piyanoda poliritm öğrenme yaklaşımlarının etkililik düzeyleri. (Yayımlanmamış doktora tezi). Gazi Üniversitesi Eğitim Bilimleri Enstitüsü, Ankara.

*Alparslan Tuncay, A. (1997). Piyano başlangıç metotlarının didaktik açıdan değerlendirilmesi. (Yayımlanmamış yüksek lisans tezi). Dokuz Eylül Üniversitesi Sosyal Bilimler Enstitüsü, İzmir.

*Alpay, T. Ö. (2010). Romantik dönemde varyasyon ve Johannes Brahms'in solo piyano için varyasyonları. (Yayımlanmamış sanatta yeterlik tezi). Dokuz Eylül Üniversitesi Güzel Sanatlar Enstitüsü, İzmir.

*Alpcan, F. B. (2009). J.S.Bach'ın geç dönem piyano eserlerinin 20. yüzyıl sanatına etkileri. (Yayımlanmamış sanatta yeterlik tezi). İstanbul Üniversitesi Sosyal Bilimler Enstitüsü, İstanbul.

*Araboğlu, A. (2006). Robert Schumann'ın piyano eserlerinde varyasyon formlarının incelenmesi. (Yayımlanmamış yüksek lisans tezi). Trakya Üniversitesi Sosyal Bilimler Enstitüsü, Edirne.

*Arslanboğa, M. (2010). Johannes Brahms'ın viyolonsel-piyano sonatlarının müzikal analizi. (Yayımlanmamış yüksek lisans tezi). Erciyes Üniversitesi Güzel Sanatlar Enstitüsü, Kayseri.

*Ata, Y. (2007). Güzel sanatlar fakültelerinde uygulanan piyano eğitiminin incelenmesi. (Yayımlanmamış yüksek lisans tezi). Erciyes Üniversitesi Sosyal Bilimler Enstitüsü, Kayseri.

*Ateş, S. N. (2011). Gara Garayev'in piyano için 24 Prelüt eserinin stil ve piyanizm özellikleri. (Yayımlanmamış yüksek lisans tezi). Erciyes Üniversitesi Güzel Sanatlar Enstitüsü, Kayseri.

*Avc1, A. (2013). Farklı liselerden mezun müzik öğretmenliği öğrencilerinin piyano çalma becerilerinin karşılaştırılması. (Yayımlanmamış yüksek lisans tezi). Dokuz Eylül Üniversitesi Eğitim Bilimleri Enstitüsü, İzmir.

*Aycan, M. O. (2011). Ĕ̈itim fakültelerinde piyano eğitiminde kullanılan bazı parçaların armonik karmaşıklık düzeyi üzerinde bir çalışma. (Yayımlanmamış yüksek lisans tezi). Dokuz Eylül Üniversitesi Eğitim Bilimleri Enstitüsü, İzmir.

*Aydıner, M. (2004). Piyano eğitimi sürecinde karşılaşılabilen bedensel rahatsızlıklar ve bu rahatsızlıkların oluşmaması için müzik eğitimi anabilim dallarında alınabilecek önlemler. (Yayımlanmamış yüksek lisans tezi). Gazi Üniversitesi Eğitim Bilimleri Enstitüsü, Ankara.

*Aydıner, M. (2008). Piyano eğitiminde makamsal yapıdaki eserlerin seslendirilmesinde karşılaşılan teknik güçlükler ve model önerileri. (Yayımlanmamış doktora tezi). Gazi Üniversitesi Eğitim Bilimleri Enstitüsü, Ankara. 
*Aydınlı, D. (2012). Gazi Eğitim Fakültesi Müzik Ĕgitimi 3. sınıf öğrencilerinin okul şarkılarını eşlikleme ve transpoze becerilerinin geliştirilmesinde grup piyano öğretiminin etkisi. (Yayımlanmamış doktora tezi). Gazi Üniversitesi Eğitim Bilimleri Enstitüsü, Ankara.

*Aydınoğlu, O. (2014). Çağdaş Türk bestecilerinin piyano eserlerinin akademik piyano eğitimi açısından incelenerek piyano eğitim seviyelerine göre sinıflandırılması. (Yayımlanmamış doktora tezi). Marmara Üniversitesi Eğitim Bilimleri Enstitüsü, İstanbul.

*Babacan, E. (2010). Başlangıç piyano ĕgitiminde algısal öğrenme stillerinin uygulanabilirliği. (Yayımlanmamış doktora tezi). Selçuk Üniversitesi Eğitim Bilimleri Enstitüsü, Konya.

*Babacan, M. D. (2009). Müzik eğitimi anabilim dallarında piyanoda eşlik dersi sürecinde caz armonisinin kullanılabilirliğinin değerlendirilmesi. (Yayımlanmamış doktora tezi). Selçuk Üniversitesi Sosyal Bilimler Enstitüsü, Konya.

*Bakıroğlu, Ç. (2012). Müzik öğretmenliği programı öğrencileri ile Devlet Konservatuarı Müzik Bölümü öğrencilerinin piyano çalgısına yönelik tutumlarının karşılaşstırılması. (Yayımlanmamış yüksek lisans tezi). Karadeniz Teknik Üniversitesi Eğitim Bilimleri Enstitüsü, Trabzon.

*Balkarlı Can, S. (2002). John Cage'in “Hazırlanmıs Piyano”su ve Endonezya geleneksel orkestrası "Gamelan". (Yayımlanmamış sanatta yeterlik tezi). Anadolu Üniversitesi Sosyal Bilimler Enstitüsü, Eskişehir.

*Barutçu, E. M. (2013). 19. yüzyll post-romantik bestecilerinden Aleksandr Skriyabin'in Op. 62 No. 6 Piyano Sonatı'nın incelenmesi. (Yayımlanmamış yüksek lisans tezi). Afyon Kocatepe Üniversitesi Sosyal Bilimler Enstitüsü, Afyonkarahisar.

*Basmacıoğlu, S. K. (2015). Sol el için piyano etütleri. (Yayımlanmamış sanatta yeterlik tezi). Anadolu Üniversitesi Güzel Sanatlar Enstitüsü, Eskişehir.

*Bayazıt Karademir, E. (2014). Güzel Sanatlar Liseleri Müzik Bölümü ögrencilerinin piyano dersi akademik başarısını etkileyen etmenlere ilişkin öğretmen görüşleri (Ege Bölgesi örneği). (Yayımlanmamış yüksek lisans tezi). Pamukkale Üniversitesi Eğitim Bilimleri Enstitüsü, Denizli.

*Berkalp, S. (2002). Beethoven'ın hayatı, eserleri ve müzik tarihindeki önemi bağlamında, Op. 58 Sol Majör 4. Piyano Konçertosunun incelenmesi. (Yayımlanmamış sanatta yeterlik tezi). Hacettepe Üniversitesi Sosyal Bilimler Enstitüsü, Ankara.

*Berki, T. (1997). Mozart'ın piyano konçertolarına ilişkin bir çerçeve kadans modeli. (Yayımlanmamış doktora tezi). Gazi Üniversitesi Fen Bilimleri Enstitüsü, Ankara.

*Berköz, L. D. (2006). Piyano ve Caz. (Yayımlanmamış yüksek lisans tezi). Mimar Sinan Güzel Sanatlar Üniversitesi Sosyal Bilimler Enstitüsü, İstanbul.

*Bilen, O. O. (2007). Öz-düzenleyerek piyano çalışmanın sınav performansına etkisi. (Yayımlanmamış doktora tezi). Abant İzzet Baysal Üniversitesi, Sosyal Bilimler Enstitüsü, Bolu.

*Bilir Eyüpoğlu, E. (2016). F. Chopın'in Op.10 no.2 kromatik etüdünün piyano tekniğine etkileri. (Yayımlanmamış yüksek lisans tezi). Anadolu Üniversitesi Güzel Sanatlar Enstitüsü, Eskişehir.

*Bucak, S. (1995). Haydn piyano sonatları. (Yayımlanmamış sanatta yeterlik tezi). Mimar Sinan Üniversitesi Sosyal Bilimler Enstitüsü, İstanbul.

*Bulut, F. (2002). Çağdaş Türk piyano müziği eserlerinin piyano eğitimi açısından incelenmesi. (Yayımlanmamış yüksek lisans tezi). Gazi Üniversitesi Eğitim Bilimleri Enstitüsü, Ankara. 
*Bulut, F. (2008). Piyano ĕgitiminde geleneksel Türk Halk Müziği kaynakl eserlerin seslendirilmesine yönelik oluşturulan bir "çoklu analiz modeli" ve bu modelin öğrenci başarısı üzerine etkileri. (Yayımlanmamış doktora tezi). Gazi Üniversitesi Eğitim Bilimleri Enstitüsü, Ankara.

*Cebeci, Ö. (2007). Chopin'in 2. piyano sonatı üzerine bir araştırma. (Yayımlanmamış yüksek lisans tezi). Mimar Sinan Güzel Sanatlar Üniversitesi Sosyal Bilimler Enstitüsü, İstanbul.

*Ceman, S. (2005). Müzik öğretmeni adaylarının piyano çalışma alışkanlıkları ve piyano çalışmalarını etkileyen faktörler. (Yayımlanmamış yüksek lisans tezi). Karadeniz Teknik Üniversitesi Sosyal Bilimler Enstitüsü, Trabzon.

*Cerit, E. (2010). Gazi Ĕ̆itim Fakültesi Güzel Sanatlar Ĕ̆itimi Bölümü müzik eğitimi anabilim dalı ögrencilerinin bireysel piyano çalışma yöntemleri ile bazı değişkenler arasındaki ilişkilerin belirlenmesi. (Yayımlanmamış yüksek lisans tezi). Gazi Üniversitesi Eğitim Bilimleri Enstitüsü, Ankara.

*Coşkuner, Ö. (2015). Yaygın müzik ĕgitimi kurumlarındaki piyano ĕgitiminin niteliği ve ögrrenci profilleri. (Yayımlanmamış yüksek lisans tezi). Ondokuzmayıs Üniversitesi Eğitim Bilimleri Enstitüsü, Samsun.

*Coşkuner, S. (2007). Türkiye'de Anadolu Güzel Sanatlar liseleri (yaylı çalgılar) bireysel çalgı eğitimi dersinde piyano eşlikli çalışmalara ilişkin öğretmen görüşleri. (Yayımlanmamış yüksek lisans tezi). Gazi Üniversitesi Eğitim Bilimleri Enstitüsü, Ankara.

*Çağlak, T. (2015). Müzik öğretmenliği programı piyano derslerinde tek el eserlerin kullanılabilirliği. (Yayımlanmamış yüksek lisans tezi). Gazi Üniversitesi Eğitim Bilimleri Enstitüsü, Ankara.

*Çakıc1, A. (2007). Bela Bartok'un müzik stili ve 3. piyano konçertosu. (Yayımlanmamış yüksek lisans tezi). Uludağ Üniversitesi Sosyal Bilimler Enstitüsü, Bursa.

*Çalgan, B. (2009). Öğrenci Prokofiev'in büyük ölçekli piyano eserlerindeki sonat allegrosu anlayışı. (Yayımlanmamış sanatta yeterlik tezi). Anadolu Üniversitesi Güzel Sanatlar Enstitüsü, Eskişehir.

*Çavuş, T. (2015). Trakya Üniversitesi Devlet Konservatuarı Müzik ve Bale Ortaokulu ve Müzik ve Sahne Sanatları Lisesi devrelerinde yardımcı piyano eğitiminin öğrenciye katkıları. (Yayımlanmamış yüksek lisans tezi). Trakya Üniversitesi Sosyal Bilimler Enstitüsü, Edirne.

*Çetiner, Ö.S. (2008). Türk Musikisi Devlet Konservatuarlar'ında piyano eğitiminin işlevselliği. (Yayımlanmamış yüksek lisans tezi). Haliç Üniversitesi Sosyal Bilimler Enstitüsü, İstanbul.

*Çetiner, Ö.S. (2013). Bir tohumun gaia defterinden, solo piyano için bir program müzik çalışması. (Yayımlanmamış sanatta yeterlik tezi). Haliç Üniversitesi Sosyal Bilimler Enstitüsü, İstanbul.

*Çevik, D. B. (2002). Claude Debussy ve piyano eğitimi. (Yayımlanmamış yüksek lisans tezi). Dokuz Eylül Üniversitesi Eğitim Bilimleri Enstitüsü, İzmir.

*Çevik, D. B. (2007). Armoni eğitimi ile piyano çalma becerileri arasındaki ilişkilerin incelenmesi. (Yayımlanmamış doktora tezi). Dokuz Eylül Üniversitesi Eğitim Bilimleri Enstitüsü, İzmir.

*Çiçek, V. (2016). Güzel sanatlar liselerinde piyano eğitiminde karşılaşılan sorunlar ve çözüm önerileri: Karadeniz bölgesi örneği. (Yayımlanmamış yüksek lisans tezi). Ordu Üniversitesi Sosyal Bilimler Enstitüsü, Ordu. 
*Çoban, Ö. (2012). Marmara bölgesindeki müzik öğretmenliği lisans programı öğrencilerinin orta öğretimdeki piyano eğitimlerine yönelik görüşlerinin değerlendirilmesi. (Yayımlanmamış yüksek lisans tezi). Trakya Üniversitesi Sosyal Bilimler Enstitüsü, Edirne.

*Çoraklı, E. (2007). Müzik öğretmeni adaylarının piyano dersindeki başarıları ile kişilik özellikleri arasındaki ilişsk. (Yayımlanmamış yüksek lisans tezi). Marmara Üniversitesi Eğitim Bilimleri Enstitüsü, İstanbul.

*Dağdeviren, M. (2006). Müzik öğretmeni yetiştiren kurumlarda piyanoda eşlik öğretimi. (Yayımlanmamış yüksek lisans tezi). Niğde Üniversitesi Sosyal Bilimler Enstitüsü, Niğde.

*Dai, D. Y. (2004). Henri Dutilleux'nün piyano sonatı ve piyano müziği. (Yayımlanmamış yüksek lisans tezi). Mimar Sinan Üniversitesi Sosyal Bilimler Enstitüsü, İstanbul.

*Daysal1, Y. (2016). Liszt Si Minor Piyano Sonatı: 20. yüzyll tonalitesi ve kompozisyon teknikleri üzerine bir çalışma. (Yayımlanmamış yüksek lisans tezi). Yaşar Üniversitesi Sosyal Bilimler Enstitüsü, İzmir.

*Dede, E. Ö. (2013). Alban Berg Op. 1 Piyano Sonatı ve yorum kılavuzu. (Yayımlanmamış sanatta yeterlik tezi). Anadolu Üniversitesi Güzel Sanatlar Enstitüsü, Eskişehir.

*Demirtaş, H. E. (2013). Müzik öğretmeni adaylarının Barok Dönemi piyano eserlerinde karşılaştıkları sorunlar ve çözüm önerileri. (Yayımlanmamış yüksek lisans tezi). Mehmet Akif Ersoy Üniversitesi Eğitim Bilimleri Enstitüsü, Burdur

*Demirtaş, S. (2011). Illköğretim 7. sinıf müzik dersinde şarkıların piyano eşlikli öğretilmesinin ögrenci kazanımlarına etkileri. (Yayımlanmamış yüksek lisans tezi). Pamukkale Üniversitesi Sosyal Bilimler Enstitüsü, Denizli.

*Develi, M. (2011). "Denes Agays Learning to Play Piano I" piyano eğitimine başlangıç metodunun hedef ve hedef davranışlar yönünden incelenmesi. (Yayımlanmamış yüksek lisans tezi). Gazi Üniversitesi Eğitim Bilimleri Enstitüsü, Ankara.

*Dinç, O. (2007). Ahmed Adnan Saygun'un op.20 Piyano Ve Keman Sonatı'nın yorumuna yönelik ve teknik zorluklar açısından incelenmesi. (Yayımlanmamış yüksek lisans tezi). Mimar Sinan Güzel Sanatlar Üniversitesi Sosyal Bilimler Enstitüsü, İstanbul.

*Doğan, Ö. (2007). Türk piyano müziğinde varyasyon formunun nazari ve icra özellikleri. (Yayımlanmamış yüksek lisans tezi). Erciyes Üniversitesi Sosyal Bilimler Enstitüsü, Kayseri.

*Doğan, Ö. (2013). Türk Beşleri'nin solo piyano eserlerinde izlenimcilik etkisi. (Yayımlanmamış doktora tezi). Erciyes Üniversitesi Güzel Sanatlar Enstitüsü, Kayseri.

*Durak, Y. (2007). Piyano ögretim programı model önerisi ve uygulamadaki görünümü. (Yayımlanmamış doktora tezi). Abant İzzet Baysal Üniversitesi, Sosyal Bilimler Enstitüsü, Bolu.

*Durmaz, G. (2009). Eşlik dersinin öğrencilerin piyano eşlik becerilerinin gelişimi üzerindeki etkileri (Gazi Ĕ̈itim Fakültesi örneği). (Yayımlanmamış Yüksek Lisans Tezi). Gazi Üniversitesi Eğitim Bilimleri Enstitüsü, Ankara.

*Duru, SS. (2001). Johannes Brahms'in piyano-keman piyano-viyola ve piyano-viyolonsel sonatları üzerine bir inceleme. (Yayımlanmamış sanatta yeterlik tezi). Dokuz Eylül Üniversitesi Sosyal Bilimler Enstitüsü, İzmir.

*Düzgüner, D. (2003). Schumann'ın Carnaval adlı eseri üzerine bir çalışma ve piyano eserlerine genel bir bakış. (Yayımlanmamış yüksek lisans tezi). Mimar Sinan Üniversitesi Sosyal Bilimler Enstitüsü, İstanbul. 
*Ebesek, Ö. (2011). Wolfgang Amadeus Mozart'ın piyano konçertolarındaki beste bütünlüğü ve performans uygulamaları. (Yayımlanmamış sanatta yeterlik tezi). Dokuz Eylül Üniversitesi Güzel Sanatlar Enstitüsü, İzmir.

*Ekinci, H. (1998). Piyano eğitimine ĕgitim fakülteleri müzik ĕgitimi bölümlerinde başlayan ögrencilerin 1. yll piyano ögretim etkinliklerinin değerlendirilmesi. (Yayımlanmamış yüksek lisans tezi). Gazi Üniversitesi Fen Bilimleri Enstitüsü, Ankara.

*Ekinci, H. (2004). Eğitim Fakülteleri Güzel Sanatlar Eğitimi Bölümü Müzik Eğitimi anabilim dalı piyano derslerinde karşılaşılan teknik alıştırmalar sorunu: hedefe uygun teknik alıştırma örnekleri. (Yayımlanmamış doktora tezi). Marmara Üniversitesi Eğitim Bilimleri Enstitüsü, İstanbul.

*Emen, D. (2001). Türkiye'de müzik öğretmeni yetiştiren kurumlarda başlangıç piyano ögretiminde uygulanan yöntem ve tekniklerin incelenmesi. (Yayımlanmamış yüksek lisans tezi). Selçuk Üniversitesi Sosyal Bilimler Enstitüsü, Konya.

*Ercan, Z. S. (2010). Piyano çalmaya bağlı sakatlanmaların önlenmesi: Sanatlar tıbbı, fizyolojik bilgilenme, destekleyici teknikler ve kişisel tutum. Türkiye'deki piyanistlerle bir çalışma. (Yayımlanmamış doktora tezi). İstanbul Teknik Üniversitesi Sosyal Bilimler Enstitüsü, İstanbul.

*Erdem, A. (2010). Ahmed Adnan Saygun'un dört piyano yapıtına ilişsin bir aksak tartı analizi: Opus 38, 45, 47, 58. (Yayımlanmamış yüksek lisans tezi). Hacettepe Üniversitesi Sosyal Bilimler Enstitüsü, Ankara.

*Erel, P. (2012). Tekirdağ Güzel Sanatlar ve Spor Lisesi 1. 2. 3. ve 4. sinıflarda piyano ögretiminde karşılaşılan zorluklar ve çözüm önerileri. (Yayımlanmamış yüksek lisans tezi). Trakya Üniversitesi Sosyal Bilimler Enstitüsü, Edirne.

*Ergene, E. (2014). Erik Satie'nin piyano eserlerindeki stilistik özellikler. (Yayımlanmamış yüksek lisans tezi). Mimar Sinan Güzel Sanatlar Üniversitesi Sosyal Bilimler Enstitüsü, İstanbul.

*Erkılıç, F. (2011). Ahmet Adnan Saygun'un piyano eserlerinde Türk halk müziğinin özellikleri. (Yayımlanmamış yüksek lisans tezi). Erciyes Üniversitesi Güzel Sanatlar Enstitüsü, Kayseri.

*Eroğlu, Ö. (2004). Piyano eğitiminde kullanılan sonatinlere ilişsin teknik çalışma yöntemleri. (Yayımlanmamış yüksek lisans tezi). Gazi Üniversitesi Eğitim Bilimleri Enstitüsü, Ankara.

*Eroğlu, Ö. (2010). Müzik eğitimi anabilim dalı öğrencilerinin piyano eserlerini ezbere çalma başarılarında analitik ezberleme yaklaşımının etkililiği. (Yayımlanmamış doktora tezi). Gazi Üniversitesi Eğitim Bilimleri Enstitüsü, Ankara.

*Fışkın, Ü. (2016). Felix Mendelssohn Bartholdy'nin Lieder Ohne Worte (Sözsüz şarkalar) yapıtının armoni ve form analizi ile solo piyano edebiyatındaki yeri. (Yayımlanmamış yüksek lisans tezi). Mimar Sinan Güzel Sanatlar Üniversitesi Sosyal Bilimler Enstitüsü, İstanbul.

*Gedikli, A. S. (2006). Debussy prelüd'lerin 20. yüzyll piyano müziği’ndeki yeri ve önemi. (Yayımlanmamış sanatta yeterlik tezi). Dokuz Eylül Üniversitesi Güzel Sanatlar Enstitüsü, İzmir.

*Göğüş, C. (2007). Mesleksel müzik eğitimi veren kurumlarda ulusal müzik kültürüne dayalı başlangıç piyano eğitimine iliş̧kin öğretmen görüssleri (Ankara ili örneği). (Yayımlanmamış Yüksek Lisans Tezi). Gazi Üniversitesi Eğitim Bilimleri Enstitüsü, Ankara.

*Göher, F. (2002). Müzik öğretmeni yetiştiren kurumlarda piyano eğitiminde pedal kullanımı. (Yayımlanmamış Yüksek Lisans Tezi). Gazi Üniversitesi Eğitim Bilimleri Enstitüsü, Ankara. 
*Göksel Erdal, G. (2005). Koordinatif-kondisyonel motorik özelliklerin geliştirilmesine yönelik antrenmanları piyano çalma performansina olan etkilerinin incelenmesi ve piyano tekniğinin hareket analizi. (Yayımlanmamış doktora tezi). Kocaeli Üniversitesi Sağlık Bilimleri Enstitüsü, Kocaeli.

*Gökşen, Z. G. (2006). Brahms ve piyano (üç evrede Brahms'ın piyanoya getirdikleri). (Yayımlanmamış sanatta yeterlik tezi). Mimar Sinan Güzel Sanatlar Üniversitesi Sosyal Bilimler Enstitüsü, İstanbul.

*Gören, B. (2014). Prokofiev erken dönem eserlerine genel bir bakış ve ilk üç piyano sonatının irdelenmesi. (Yayımlanmamış sanatta yeterlik tezi). Dokuz Eylül Üniversitesi Güzel Sanatlar Enstitüsü, İzmir.

*Görsev, A. (2006). Abant İzzet Baysal Üniversitesi Müzik Ĕ̈itimi anabilim dalı son sinıf ögrencilerinin "piyano eğitimi", "müzik teorisi ve işitme eğitimi" ve "eşlik (korepetisyon)" dersleri ile okul şarkılarına doğaçlama eşlik becerileri arasındaki ilişkiler. (Yayımlanmamış yüksek lisans tezi). Abant İzzet Baysal Üniversitesi, Sosyal Bilimler Enstitüsü, Bolu.

*Grancer, N. (2004). Dans formunda yazllan piyano eserlerinin dönemlere göre sinıflandırılması, analizleri ve teknik açıdan incelenmesi. (Yayımlanmamış yüksek lisans tezi). Kocaeli Üniversitesi Sosyal Bilimler Enstitüsü, Kocaeli.

*Grançer Okay, N. (2010). Piyano performansının değerlendirilmesi. (Yayımlanmamış doktora tezi). Marmara Üniversitesi Eğitim Bilimleri Enstitüsü, İstanbul.

*Güdek, B. (2004). T.C. Üniversiteleri Güzel Sanatlar Fakültesi Müzik Bilimleri Bölümü ve Konservatuar Müzikoloji Bölümü ögrretim elemanları ile son sinıf öğrencilerinin piyano eğitimine ilişkin görüşleri. (Yayımlanmamış Yüksek Lisans Tezi). Gazi Üniversitesi Eğitim Bilimleri Enstitüsü, Ankara.

*Güldoğan, A. (1999). Ulvi Cemal Erkin’in piyano eserleri aractlĭglyla, geleneksel müziklerimizden, çağdaş Türk müzik sanatına taşıdığı müzikal unsurların incelenmesi. (Yayımlanmamış yüksek lisans tezi). Uludağ Üniversitesi Sosyal Bilimler Enstitüsü, Bursa.

*Güleç Ersoy, K. S. (2010). Altı yaş çocuklarının piyano eğitimine hazırlanmalarında kullanılan yöntemlerin incelenmesi. (Yayımlanmamış yüksek lisans tezi). Ankara Üniversitesi Eğitim Bilimleri Enstitüsü, Ankara.

*Gültek, B. (2004). Piyano eğitiminde varolan eğitim ekollerinin felsefeleri ve günümüz çalışmalarında kullanılabilirlikleri hakkında öğretim elemanlarının görüşleri (G.Ü.G.E.F.). (Yayımlanmamış yüksek lisans tezi). Gazi Üniversitesi Eğitim Bilimleri Enstitüsü, Ankara.

*Gün, E. (2007). Müzik öğretmeni adaylarının piyano dersindeki başarı durumları ve başarılarını etkileyen faktörler. (Yayımlanmamış yüksek lisans tezi). Süleyman Demirel Üniversitesi Sosyal Bilimler Enstitüsü, Isparta.

*Gün, E. (2014). Piyano performansı öz yeterlik ölçeğinin geliştirilmesi ve uygulanması. (Yayımlanmamış doktora tezi). Mehmet Akif Ersoy Üniversitesi Eğitim Bilimleri Enstitüsü, Burdur.

*Güncan, Ö. (2010). Robert Schumann ve Op.22 Piyano Sonatı üzerine bir analiz. (Yayımlanmamış yüksek lisans tezi). Anadolu Üniversitesi Güzel Sanatlar Enstitüsü, Eskişehir.

*Gürün, G. (2013). Bartok'un iki piyano ve vurmalılar için Sonat'ının ikinci muvmanında fibonacci sayıları. (Yayımlanmamış yüksek lisans tezi). Hacettepe Üniversitesi Sosyal Bilimler Enstitüsü, Ankara. 
*Güven, G. (2010). Piyanonun gelişimi ve teknik yönden romantik dönemin sonuna kadar incelenmesi. (Yayımlanmamış yüksek lisans tezi). İstanbul Üniversitesi Sosyal Bilimler Enstitüsü, İstanbul.

*Güvençer, R. (2006). Ahmed Adnan Saygun'un op.12 viyolonsel-piyano sonatını teknik açıdan ve yoruma yönelik inceleyen çalışma kılavuzu. (Yayımlanmamış yüksek lisans tezi). Mimar Sinan Güzel Sanatlar Üniversitesi Sosyal Bilimler Enstitüsü, İstanbul.

*Hanönü, Y. (2007). Askeri bando çalgılarının, çalgılama tekniklerine uygun olarak incelenmesi ve Claude Debussy'nin Children's Corner adll piyano eserinin askeri bando çalgılama tekniklerine uygun olarak orkestrasyonunun yapılması. (Yayımlanmamış yüksek lisans tezi). Cumhuriyet Üniversitesi Sosyal Bilimler Enstitüsü, Erzurum.

*Hasanova, A. (2008). Türkiye'de ve Azerbaycan'da müzik eğitimi veren kurumların ilkögrretim ve ortä̈gretim düzeyinde verilen piyano eğitimi programlarının değerlendirilmesi. (Yayımlanmamış yüksek lisans tezi). Uludağ Üniversitesi Sosyal Bilimler Enstitüsü, Bursa.

*Hendekli, Z. M. (2008). Ravel ve solo piyano eserlerindeki müzik-dışı çağrışımlar-Ravel and his extra-musical associations in solo piano works. (Yayımlanmamış doktora tezi). İstanbul Teknik Üniversitesi Sosyal Bilimler Enstitüsü, İstanbul.

*Kahramansoy, C. (2006). Müzik öğretmenliği programlarında görevli piyano öğretim elemanlarının müzik alan bilgisini derse transferi: Bir üniversite örneği. (Yayımlanmamış yüksek lisans tezi). Abant İzzet Baysal Üniversitesi, Sosyal Bilimler Enstitüsü, Bolu.

*Kaleli, Y. S. (2014). Müzik öğretmeni adaylarının piyano eğitimi sürecinde kazandıkları teknik davranışların incelenmesi: Necmettin Erbakan Üniversitesi örneği. (Yayımlanmamış yüksek lisans tezi). Necmettin Erbakan Üniversitesi Eğitim Bilimleri Enstitüsü, Konya.

*Kalkanoğlu, B. (2007). Okul şarkılarının müzik öğretmenlerinin bilgi ve beceri düzeyine göre piyano ile eşliklenmesine yönelik bir eşlik modeli önerisi. (Yayımlanmamış yüksek lisans tezi). Gazi Üniversitesi Eğitim Bilimleri Enstitüsü, Ankara.

*Kalyoncu, N. (1996). Anadolu Güzel Sanatlar Liseleri müzik bölümlerinde piyano ögretim programlarının hedeflerine ulaşma durumu. (Yayımlanmamış yüksek lisans tezi). Abant İzzet Baysal Üniversitesi, Sosyal Bilimler Enstitüsü, Bolu.

*Karabey, S. G. (2016). Johannes Brahms'in Op. 99 Fa Majör Viyolonsel-Piyano Sonatı'nı yorumlama teknikleri. (Yayımlanmamış yüksek lisans tezi). Mimar Sinan Güzel Sanatlar Üniversitesi Güzel Sanatlar Enstitüsü, İstanbul.

Karabulut, G. (2009). Eğitim fakültesi müzik eğitimi anabilim dalı 1.ve 3.sinıf ögrencilerinin piyano dersine yönelik tutumlarının incelenmesi. (Yayımlanmamış yüksek lisans tezi). Gazi Üniversitesi Eğitim Bilimleri Enstitüsü, Ankara.

*Karaçil, V. (2010). Ludwig van Beethoven'in Op. 90 mi minör, Op.101 La Majör, Op.109 Mi Majör, Op.110 La bemol Majör piyano sonatlarının incelenmesi. (Yayımlanmamış yüksek lisans tezi). Dokuz Eylül Üniversitesi Güzel Sanatlar Enstitüsü, İzmir.

*Karahan, A. S. (2004). Türkiye'deki müzik öğretmeni yetiştiren kurumların piyano öğretimi sürecinde kullanılan Klasik Batı müziği piyano etütlerinin öğrencileri Çăgdaş Türk Müziği piyano eserlerini çalmaya hazırlama durumu. (Yayımlanmamış yüksek lisans tezi). Gazi Üniversitesi Eğitim Bilimleri Enstitüsü, Ankara.

*Karahan, A. S. (2008). Çă̆daş Türk müziği piyano eserlerine hazırlık amacıyla yazılan etütlerin ögrencilerin eserleri çalma düzeylerine etkisinin belirlenmesi. (Yayımlanmamış doktora tezi). Gazi Üniversitesi Eğitim Bilimleri Enstitüsü, Ankara. 
*Karanis, G. (2011). Eğitim fakülteleri müzik ĕgitimi anabilim dallarında bulunan piyanoların sayı ve nitelik bakımından yeterlilik durumuna ilişkin öğrenci görüşleri. (Yayımlanmamış yüksek lisans tezi). Gazi Üniversitesi Eğitim Bilimleri Enstitüsü, Ankara.

*Karataş, K. O. (2015). Türkiye'de mesleki müzik eğitimi veren kurumlardaki piyano ders içeriklerinin incelenmesi. (Yayımlanmamış yüksek lisans tezi). Atatürk Üniversitesi Eğitim Bilimleri Enstitüsü, Erzurum.

*Karlıdağ, M. S. (2016). Johannes Brahms'ın Opus 38 Mi Minör Viyolonsel-Piyano Sonatı'nın güncel bir anlayışla incelenmesi. (Yayımlanmamış yükssek lisans tezi). Mimar Sinan Güzel Sanatlar Üniversitesi Güzel Sanatlar Enstitüsü, İstanbul.

*Karul, Y. (2014). Türkiye'de piyano bakım, onarım ve akort meselesi. (Yayımlanmamış yüksek lisans tezi). Trakya Üniversitesi Sosyal Bilimler Enstitüsü, Edirne.

*Kayal1, B. (2013). Piyanonun Türk musikisi icra ve kuramına etkisinin değerlendirilmesi. (Yayımlanmamış yüksek lisans tezi). Trakya Üniversitesi Sosyal Bilimler Enstitüsü, Edirne.

*Kaynak, T. (2004). Okul öncesi çocuklara yönelik piyano metotlarının incelenerek kullanılma durumlarının saptanması. (Yayımlanmamış Yüksek Lisans Tezi). Gazi Üniversitesi Eğitim Bilimleri Enstitüsü, Ankara.

*K1lıç, I. (2003). Eğitim Fakülteleri Güzel Sanatlar Eğitimi Bölümü Müzik Eğitimi anabilim dalı öğrencilerinin piyano eğitiminde başarlyı etkileyen faktörlere ilişkin görüşlerin değerlendirilmesi. (Yayımlanmamış yüksek lisans tezi). Gazi Üniversitesi Eğitim Bilimleri Enstitüsü, Ankara.

*K1lıçer, Ö. (2009). Anadolu Güzel Sanatlar Liseleri müzik bölümü öğrencilerinin piyano dersine yönelik tutumlarının incelenmesi. (Yayımlanmamış yüksek lisans tezi). İnönü Üniversitesi Sosyal Bilimler Enstitüsü, Malatya.

*Kılınçer, Ö. (2013). Piyano dersinde kullanılan öğrenme stratejilerinin çeşitli değişkenler açısından incelenmesi. (Yayımlanmamış doktora tezi). Erciyes Üniversitesi Güzel Sanatlar Enstitüsü, Kayseri.

*Kızılay, E. (2013). Horon ezgilerinden yola çıkarak çok sesli tonal müzik odaklı bir kompozisyon denemesi: Keman ve piyano için "Tepebaşı Horon". (Yayımlanmamış yüksek lisans tezi). Haliç Üniversitesi Sosyal Bilimler Enstitüsü, İstanbul.

*Kocatürk, A. (2010). Piyano çalma teknikleri. (Yayımlanmamış sanatta yeterlik tezi). İstanbul Üniversitesi Sosyal Bilimler Enstitüsü, İstanbul.

*Koçak, B. (2007). Geleneksel Türk sanat müziğinin piyano ile icrasında kullanılan süsleme teknikleri. (Yayımlanmamış Doktora Tezi). Gazi Üniversitesi Eğitim Bilimleri Enstitüsü, Ankara.

*Köse, Y. (2013). Piyano eğitiminde hızlı deşifre teknikleri üzerine bir çalışma. (Yayımlanmamış yüksek lisans tezi). Atatürk Üniversitesi Sosyal Bilimler Enstitüsü, Erzurum.

*Köseoğlu, B. (2013). Romantizmden modernizme uzanan süreçte Alexander Scriabin'in piyano yapıtları. (Yayımlanmamış yüksek lisans tezi). Dokuz Eylül Üniversitesi Güzel Sanatlar Enstitüsü, İzmir.

*Kulaoğlu Tonger, S. (2013). Piyanonun Türk kültürüne uyumunun, eğitim fakülteleri bünyesinde incelenmesi. (Yayımlanmamış doktora tezi). Yeditepe Üniversitesi Sosyal Bilimler Enstitüsü, İstanbul. 
*Kurşunet, H. B. (2014). Cemal Reşit Rey'in iki piyano için 12 prelüd ve füg adl eserinde polifonik form ve usullerin incelenmesi. (Yayımlanmamış yüksek lisans tezi). Erciyes Üniversitesi Güzel Sanatlar Enstitüsü, Kayseri.

*Kurtuldu, M. K. (2007). Bilgiyi işleme modeline dayal piyano eğitiminde genel öğrenme stratejilerinin yeri ve görsel imajlar oluşturma yönteminin kullanılabilirlik düzeyi. (Yayımlanmamış Doktora Tezi). Gazi Üniversitesi Eğitim Bilimleri Enstitüsü, Ankara.

*Kutluk, Ö. (2001). Türkiye'deki müzik öğretmeni yetiştiren kurumlarda piyano eğitimi. (Yayımlanmamış doktora tezi). Gazi Üniversitesi Fen Bilimleri Enstitüsü, Ankara.

*Kuyumcu, M. (2010). 18. ve 19. yüzyıl piyano eşlikli keman sonatlarında piyanonun değişen rolü. (Yayımlanmamışs sanatta yeterlik tezi). İstanbul Üniversitesi Sosyal Bilimler Enstitüsü, İstanbul.

*Küçük, G. (2010). 20. yüzyıl başlarında piyano müziğinde Viyana ve Paris. (Yayımlanmamış yüksek lisans tezi). Hacettepe Üniversitesi Sosyal Bilimler Enstitüsü, Ankara.

*Küçükçelebi, A. S. (2010). L.Van Beethoven op.12 no:1, 2, 3 piyano ve keman sonatlarınin yoruma dayalı incelemesi. (Yayımlanmamış yüksek lisans tezi). Mimar Sinan Güzel Sanatlar Üniversitesi Sosyal Bilimler Enstitüsü, İstanbul.

*Küngerü, S. (2014). Piyano öğretiminde teknik becerilerin geliştirilmesinin incelenmesi. (Yayımlanmamış sanatta yeterlik tezi). Trakya Üniversitesi Sosyal Bilimler Enstitüsü, Edirne.

*Küpana, M. N. (2008). Müzik öğretmeni adaylarının piyano pedagojisine yönelik algıladıkları yeterlilikler. (Yayımlanmamış yüksek lisans tezi). Marmara Üniversitesi Eğitim Bilimleri Enstitüsü, İstanbul.

*Küpana, M. N. (2011). Müzik öğretmeni adaylarına yönelik geliştirilen piyanoda deşifre ögretimi programının etkililiğinin sınanması. (Yayımlanmamış doktora tezi). Marmara Üniversitesi Eğitim Bilimleri Enstitüsü, İstanbul.

*Lehimler, E. (2012). Müzik öğretmeni yetiştiren kurumlarda bilgisayar derslerinde öğretilen müzik programlarının ve yazılımlarının piyano eğitimine katkılarının incelenmesi. (Yayımlanmamış yüksek lisans tezi). Atatürk Üniversitesi Eğitim Bilimleri Enstitüsü, Erzurum.

*Mammadova, T. (2015). J.S. Bach'ın özgün eserlerinin Romantik Dönem bestecilerinin piyano transkripsiyonları ile karşılaştırılması. (Yayımlanmamış sanatta yeterlik tezi). İstanbul Üniversitesi Sosyal Bilimler Enstitüsü, İstanbul.

Mamudova, H. (2005). Shumann'in piyano eserleri ve liedlerindeki edebi etkileşimler. (Yayımlanmamış yüksek lisans tezi). Hacettepe Üniversitesi Sosyal Bilimler Enstitüsü, Ankara.

*Mest, B. (2010). Franz Liszt'in La Major (S.125) Ikkinci Piyano konçertosunun incelenmesi. (Yayımlanmamış yüksek lisans tezi). Hacettepe Üniversitesi Sosyal Bilimler Enstitüsü, Ankara.

*Mete, M. (2004). Gazi Üniversitesi Güzel Sanatlar Ĕ̆itimi Bölümü Müzik Öğretmenliği Anabilim Dalında piyano öğretiminde kullanılan Czerny op.599 etütlerinin piyano eğitimi açısından değerlendirilmesi. (Yayımlanmamış yüksek lisans tezi). Gazi Üniversitesi Eğitim Bilimleri Enstitüsü, Ankara.

*Milli, M. S. (1999). İlköğretim okullarında piyano ve klavyeli çalgıların müzik öğretmenleri tarafindan kullanımı ve eğitime katkıları. (Yayımlanmamış yüksek lisans tezi). Pamukkale Üniversitesi Sosyal Bilimler Enstitüsü, Denizli. 
*Minez, T. (2012). Piyano eğitiminde rubrik ile geleneksel ölçme-değerlendirme yöntemlerinin karşılaştırılması: İnönü Üniversitesi örneği. (Yayımlanmamış yüksek lisans tezi). İnönü Üniversitesi Eğitim Bilimleri Enstitüsü, Malatya.

*Modiri, I. G. (2002). Polifoni'nin piyano eğitimindeki önemi. (Yayımlanmamış yüksek lisans tezi). Karadeniz Teknik Üniversitesi Sosyal Bilimler Enstitüsü, Trabzon.

*Modiri, I. G. (2009). Okul öncesi dönemi 60-72 aylık çocuklar için Çoklu Zeka Kuramına göre düzenlenmiş bir müzik eğitimi ve bireysel enstrüman eğitimi programı gelişstirilmesi: Piyano eğitimi örneği. (Yayımlanmamış doktora tezi). Marmara Üniversitesi Eğitim Bilimleri Enstitüsü, İstanbul.

*Mumcu, M. D. (2002). Anadolu Güzel Sanatlar Liselerinde uygulanan piyano eğitiminin program, ögretmen, ögrenci ve çalışma ortamı değişkenlerine göre değerlendirilmesi. (Yayımlanmamış yüksek lisans tezi). Abant İzzet Baysal Üniversitesi Sosyal Bilimler Enstitüsü, Bolu.

*Niksiç, N. (2015). Franz Liszt'in I. Piyano Konçertosu'nun (Mi bemol majör) incelemesi. (Yayımlanmamış sanatta yeterlik tezi). Hacettepe Üniversitesi Güzel Sanatlar Enstitüsü, Ankara.

*Oğan, F. D. (2012). Piyano öğretiminde Carl Czerny Op. 599 ve Jean-Baptiste Duvernoy Op. 176 Metodlarında yer alan etüdlerin klasik dönem sonatın icralarına etki durumu. (Yayımlanmamış yüksek lisans tezi). Gazi Üniversitesi Eğitim Bilimleri Enstitüsü, Ankara.

*Okan, C. (2009). F. Liszt'in piyanoya uyarlama sanatı ve buna bir örnek olarak L. Van Beethoven'in 5. Senfonisi'nin analizi. (Yayımlanmamııs yüksek lisans tezi). Mimar Sinan Güzel Sanatlar Üniversitesi Sosyal Bilimler Enstitüsü, İstanbul.

*Okan. H. (2009). Piyano eğitiminde yansitıcı düşünmenin kullanımı ve etkililiği (Devlet konservatuarları ses eğitimi anasanat dalları örneği). (Yayımlanmamış doktora tezi). Gazi Üniversitesi Eğitim Bilimleri Enstitüsü, Ankara.

*Okay, B. D. (2013). Caz piyano müziğinin piyano ĕgitiminde kullanılabilirliği. (Yayımlanmamış doktora tezi). Marmara Üniversitesi Eğitim Bilimleri Enstitüsü, İstanbul.

*Onuray, H. (1998). 6-8 yaş çocukları için piyano başlangıç aşamasında öğrenmeyi hızlandırıcı ve pekiştirici görsel çalı̧̧malar. (Yayımlanmamış yüksek lisans tezi). Gazi Üniversitesi Fen Bilimleri Enstitüsü, Ankara.

*Orhan, E. (2016). Güzel sanatlar liselerinde öğrenim gören öğrencilerin piyanoda etkili çalışma durumları. (Yayımlanmamış yüksek lisans tezi). Niğde Üniversitesi Eğitim Bilimleri Enstitüsü, Niğde.

*Orkut, B. E. (2009). Piyano Konçertosu ile Türk bestecilerin piyano konçertolarında ele aldıkları konçertant öğelerin saptanması. (Yayımlanmamış yüksek lisans tezi). Mimar Sinan Güzel Sanatlar Üniversitesi Sosyal Bilimler Enstitüsü, İstanbul.

*Otacıŏlu, S. G. (2005). Müzik öğretmenliği piyano eğitimi dersi için bir model denemesi. (Yayımlanmamış doktora tezi). Marmara Üniversitesi Eğitim Bilimleri Enstitüsü, İstanbul.

*Ömür, Ö. (1998). Piyano öğretiminde pedagojik yaklaşımın önemi üzerine bir araştırma. (Yayımlanmamış yüksek lisans tezi). Gazi Üniversitesi Fen Bilimleri Enstitüsü, Ankara.

*Ömür, Ö. (2003). Piyano eğitiminde nöro linguistik programlama tekniklerinin öğrenci başarısı üzerindeki etkileri. (Yayımlanmamış doktora tezi). Gazi Üniversitesi Eğitim Bilimleri Enstitüsü, Ankara. 
*Önal, D. (2010). Giuseppe Verdi'nin"La Traviata" operasının piyano eşlik problemleri. (Yayımlanmamış yüksek lisans tezi). Çukurova Üniversitesi, Sosyal Bilimler Enstitüsü, Adana.

*Önal, E. (2005). Henry Cowell'ın piyanodan farklı tını elde etme teknikleri. (Yayımlanmamış sanatta yeterlik tezi). Bilkent Üniversitesi Müzik ve Sahne Sanatları Enstitüsü, Ankara.

*Öz, Ç. (1999). Anadolu Güzel Sanatlar Liselerinden Gazi Üniversitesi Gazi Eğitim Fakültesi Müzik Eğitimi Bölümüne gelen öğrencilerin piyano dersindeki başarllarının değerlendirilmesi. (Yayımlanmamış yüksek lisans tezi). Gazi Üniversitesi Fen Bilimleri Enstitüsü, Ankara.

*Özçelebi, B. (2008). 5-6 yaş grubu piyano eğitimi gören ve piyano eğitimi görmeyen çocukların motor becerilerinin karşılaş̧tıılması. (Yayımlanmamış yüksek lisans tezi). Gazi Üniversitesi Eğitim Bilimleri Enstitüsü, Ankara.

*Özçelik, Ö. A. (2001). Suzuki yönteminin piyano eğitiminin başlangıç aşamasına uyarlanması. (Yayımlanmamış yüksek lisans tezi). Abant İzzet Baysal Üniversitesi Sosyal Bilimler Enstitüsü, Bolu.

*Özçelik, Ö. A. (2009). Suzuki yetenek eğitimi ve Bartok Mikrokosmos yöntemleriyle özengen piyano eğitiminde yoğunlaşma becerisi. (Yayımlanmamış doktora tezi). Abant İzzet Baysal Üniversitesi Sosyal Bilimler Enstitüsü, Bolu.

*Özdemir, Ö. (2007). Osmanlı İmparatorluğu Dönemi'nde yazllan piyano eserleri üzerine analitik inceleme. (Yayımlanmamış yüksek lisans tezi). Afyonkarahisar Kocatepe Üniversitesi Sosyal Bilimler Enstitüsü, Afyonkarahisar.

Özdemir, Y. U. (2012). Müzik öğretmeni adaylarının piyano pedallarına ilişkin bilgi düzeyleri ile pedal kullanma becerilerine ait algllarının değerlendirilmesi. (Yayımlanmamış yüksek lisans tezi). Mehmet Akif Ersoy Üniversitesi Sosyal Bilimler Enstitüsü, Burdur.

*Özdemir, Z. (2008). Rachmaninov'un piyano konçertolarının ve lied eşliklerinin incelenmesi. (Yayımlanmamış yüksek lisans tezi). İstanbul Üniversitesi Sosyal Bilimler Enstitüsü, İstanbul.

*Özel, I. (2012). Bireysel ses eğitiminde piyano eşliğinin önemi. (Yayımlanmamış yüksek lisans tezi). Afyon Kocatepe Üniversitesi Sosyal Bilimler Enstitüsü, Afyonkarahisar.

*Özer, B. (2010). Piyano öğretiminde deşifre becerisinin kazandırılması. (Yayımlanmamış yüksek lisans tezi). Selçuk Üniversitesi, Eğitim Bilimleri Enstitüsü, Konya.

*Özer, B. (2014). Piyano eğitiminde çözümleme destekli çalışma metodunun işlevsel piyano çalma becerilerine etkisi. (Yayımlanmamış doktora tezi). Necmettin Erbakan Üniversitesi Eğitim Bilimleri Enstitüsü, Konya.

*Özer, Z. (2010). Bursa Zeki Müren Güzel Sanatlar ve Spor Lisesi Müzik Bölümü piyano dersinde kullantlan anlamlandırma stratejilerinin ögrencilerin öğrenme düzeylerine ve tutumlarına etkisi. (Yayımlanmamış yüksek lisans tezi). Balıkesir Üniversitesi Sosyal Bilimler Enstitüsü, Balıkesir.

*Özkan, T. (2010). Johannes Brahms'ın piyanolu dörtlülerinde viyolanın kullanımı. (Yayımlanmamış sanatta yeterlik tezi). Mimar Sinan Güzel Sanatlar Üniversitesi Sosyal Bilimler Enstitüsü, İstanbul.

*Özkan, V. (2011). Anna Nikolayevna Yesipova'nın sanatsal formasyonu ve piyano ögretim yöntemi. (Yayımlanmamış yüksek lisans tezi). Ondokuzmayıs Üniversitesi Ĕ̆itim Bilimleri Enstitüsü, Samsun. 
*Özkan, Y. (2001). Johann Sebastian Bach’in piyano müziğindeki süsleme teknikleri üzerine bir çalışma. (Yayımlanmamış yüksek lisans tezi). Selçuk Üniversitesi Sosyal Bilimler Enstitüsü, Konya.

*Öztürk, B. (2006). Piyano eğitiminde video kamera kaydına dayalı mikro öğretim yönteminin ögrenci başarısına etkisi. (Yayımlanmamış doktora tezi). Gazi Üniversitesi Eğitim Bilimleri Enstitüsü, Ankara.

*Öztürk, S. (2011). Müzik öğretmenliği programında alınan piyano eğitiminin müzik ögretmeninin mesleki yaşamına katkısı. (Yayımlanmamış yüksek lisans tezi). İnönü Üniversitesi Eğitim Bilimleri Enstitüsü, Malatya.

*Pakel, H. (2014). Güzel sanatlar liselerindeki piyanoların akort, bakım ve onarım sorunlarının değerlendirilmesi. (Yayımlanmamış yüksek lisans tezi). Uludağ Üniversitesi Eğitim Bilimleri Enstitüsü, Bursa.

*Peşinci, F. A. (2014). Kodály yönteminin Saygun ve Bartok piyano repertuarına uygulanmast. (Yayımlanmamış yüksek lisans tezi). Haliç Üniversitesi Sosyal Bilimler Enstitüsü, İstanbul.

*Petenkaya, S. (2006). Piyano öğrencilerinin barok dönem süslemelerine ilişkin bilgi ve performans düzeylerinin saptanması. (Yayımlanmamış yüksek lisans tezi). Gazi Üniversitesi Eğitim Bilimleri Enstitüsü, Ankara.

*Pirgon, Y. (2009). Piyano eğitiminde karşılaşılan teknik güçlüklerin aşılmasına yönelik bir uygulama. (Yayımlanmamış doktora tezi). Selçuk Üniversitesi Sosyal Bilimler Enstitüsü, Konya.

*Pirlibeylioğlu, B. (2015). Müzik eğitimi anabilim dalı 3. ve 4. sinıf öğrencilerinin piyano performansı özyeterlik algıları ile piyano öğretim elemanlarının ögrencilerin piyano performansı hakkındaki görüşleri: Ege bölgesi örneği. (Yayımlanmamış yüksek lisans tezi). Pamukkale Üniversitesi Eğitim Bilimleri Enstitüsü, Denizli.

*Santepe, S. Y. (2013). L. V. Beethoven'in Op.13 patetik piyano sonatının armoni, form bilgisi ve çözümleme teknikleri derslerine katkılarının incelenmesi. (Yayımlanmamış yüksek lisans tezi). Dokuz Eylül Üniversitesi Eğitim Bilimleri Enstitüsü, İzmir.

*Sayın, E. (2016). M. P. Mussorgsky Bir Sergiden Tablolar adl piyano eserinin teknik ve müzikal analizi. (Yayımlanmamış yüksek lisans tezi). Dokuz Eylül Üniversitesi Güzel Sanatlar Enstitüsü, İzmir.

*Sel, B. (2003). L. Van Beethoven'in geç dönem piyano sonatlarl, Op.101, 106, 109, 110 ve özellikle Op.111'in incelenmesi. (Yayımlanmamış yüksek lisans tezi). Hacettepe Üniversitesi Sosyal Bilimler Enstitüsü, Ankara.

*Selen, B. (2009). İspanyol piyano müziğinde otantisite ve piyano tekniğinin evrimi üzerine bir çalışma-Albeniz Granados ve Falla’nın eserlerinden örnekler. (Yayımlanmamış doktora tezi). İstanbul Teknik Üniversitesi Sosyal Bilimler Enstitüsü, İstanbul.

*Sever, D. (2003). Mozart Lied'lerde piyano eşliği. (Yayımlanmamış yüksek lisans tezi). İstanbul Üniversitesi Sosyal Bilimler Enstitüsü, İstanbul.

*Sever, D. (2016). D.D. Şostakoviç'in piyano eserlerinden 24 prelüt ve füg'ün müzik edebiyatındaki yeri ve J.S.Bach'ın 48 prelüt ve füg'ü ile kontrpuan açısından karşslaşstırlması. (Yayımlanmamış sanatta yeterlik tezi). İstanbul Üniversitesi Sosyal Bilimler Enstitüsü, İstanbul.

*Sonakin, E. M. (2009). İlhan Usmanbaş'ın klarinet ve piyano için üç sonatini (üç sonatinin çalgı ve yazı teknikleri bakımından bestecinin diğer klarinet müzikleriyle ele alınması). (Yayımlanmamış sanatta yeterlik tezi). Mimar Sinan Güzel Sanatlar Üniversitesi Sosyal Bilimler Enstitüsü, İstanbul. 
*Suvat, E. (2009). Dmitriy Shostakovich'in son eseri op. 147 viyola ve piyano sonatınin tarihsel, teorik ve formal incelemesi. (Yayımlanmamış yüksek lisans tezi). Trakya Üniversitesi Sosyal Bilimler Enstitüsü, Edirne.

*Şahin, P. (2011). Güzel sanatlar ve spor liselerinde piyano ögretim programında kullanılan makamların uygulanabilirliği hakkında ögrretmen ve ögrenci görüşleri. (Yayımlanmamış yüksek lisans tezi). Gazi Üniversitesi Eğitim Bilimleri Enstitüsü, Ankara.

*Şahinalp, A. G. (2006). Romantizm ışığında Schumann'ın piyanolu ikili ve üçlü eserlerinin incelenmesi. (Yayımlanmamış sanatta yeterlik tezi). İstanbul Üniversitesi Sosyal Bilimler Enstitüsü, İstanbul

*Şen, M. (2012). Türkiye'de müzik eğitimi veren güzel sanatlar fakültelerindeki temel piyano dersinde kullanılan metotların incelenmesi. (Yayımlanmamış yüksek lisans tezi). Atatürk Üniversitesi Sosyal Bilimler Enstitüsü, Erzurum.

*Tan, Z. (2009). Francis Poulenc obua ve piyano sonatınin form, analiz ve icra yönünden incelenmesi. (Yayımlanmamış yüksek lisans tezi). Trakya Üniversitesi Sosyal Bilimler Enstitüsü, Edirne.

*Tarkum, G. (2011). Piyano için yazılmış eserlerin seslendirilmesinde pedal kullanımının Incelenmesi. (Yayımlanmamış sanatta yeterlik tezi). Trakya Üniversitesi Sosyal Bilimler Enstitüsü, Edirne.

*Tezer, A. E. (2010). Anadolu güzel sanatlar liselerinde piyano eğitimi alan öğrencilerin karşılaşstıları teknik problemlerin incelenmesi. (Yayımlanmamış yüksek lisans tezi). Dokuz Eylül Üniversitesi Eğitim Bilimleri Enstitüsü, İzmir.

*Tezer, F. (2013). Sanat Tıbbı ve piyano tekniğinin işlevsel biyomekaniği Czerny ve Brahms egzersizler desteği ile Chopin ve Liszt etüdlerin çalışma yöntemleri. (Yayımlanmamış doktora tezi). İstanbul Üniversitesi Sosyal Bilimler Enstitüsü, İstanbul.

*Tokcan, A. (1998). Piyano Eğitiminde Kullanılan Başlangıç Metotlarından “J.A. Burkard'ın (Band-I) Hedef-Hedef Davranış ve İçerik Yönünden Incelenmesi. (Yayımlanmamış yüksek lisans tezi). Gazi Üniversitesi Fen Bilimleri Enstitüsü, Ankara.

*Topalak, Ş. (2016). Çevrilmiş öğrenme modelinin başlangıç seviyesi piyano öğretimine etkisi. (Yayımlanmamış doktora tezi). İnönü Üniversitesi Eğitim Bilimleri Enstitüsü, Malatya.

*Toptaş, B. (2008). Güzel sanatlar eğitimi anabilim dalı müzik öğretmenliği programlarında piyano eğitimine deneysel yaklaşım. (Yayımlanmamış yüksek lisans tezi). Cumhuriyet Üniversitesi Sosyal Bilimler Enstitüsü, Erzurum.

*Toptaş, B. (2012). Halk türkülerinin sistematik olarak piyano eğitiminde kullanılması. (Yayımlanmamış doktora tezi). İnönü Üniversitesi Eğitim Bilimleri Enstitüsü, Malatya.

*Tözeniş, A. (2009). Ludwig Van Beethoven'in, Mozart'ın 'Sihirli Flüt Operası'na ait "Bei Mannern, Welche Liebe Fühlen" düeti üzerine piyano ve çello için 7 varyasyon sonatı ile Ludwig Van Beethoven'in diğer eserlerinin karşılaştırılması. (Yayımlanmamış yüksek lisans tezi). Mimar Sinan Güzel Sanatlar Üniversitesi Sosyal Bilimler Enstitüsü, İstanbul.

*Tuğrul, E. G. (2012). Bela Bartok'un piyano sonatı 1926. (Yayımlanmamış yüksek lisans tezi). Mimar Sinan Güzel Sanatlar Üniversitesi Sosyal Bilimler Enstitüsü, İstanbul.

*Tuğrul, E. G. (2015). W.A.Mozart'ın piyano sonatları. (Yayımlanmamış sanatta yeterlik tezi). Mimar Sinan Güzel Sanatlar Üniversitesi Sosyal Bilimler Enstitüsü, İstanbul.

*Tunalı, S. (2014). Halkevlerinde yürütülen müzik ve piyano çalışmalarının incelenmesi. (Yayımlanmamış sanatta yeterlik tezi). Trakya Üniversitesi Sosyal Bilimler Enstitüsü, Edirne. 
*Tunç, T. (2009). Müzik öğretmenliği programı anabilim dallarında uygulanan armonikontrpuan-eşlik derslerinde piyanonun kullanabilme durumunun incelenmesi. (Yayımlanmamış yüksek lisans tezi). Gazi Üniversitesi Eğitim Bilimleri Enstitüsü, Ankara.

*Tunç, T. (2016). Piyano ögretiminde Türk müziği kaynakl kontrpuantal eserlerin seslendirilmesine yönelik bir çalışma modeli. (Yayımlanmamış doktora tezi). Gazi Üniversitesi Eğitim Bilimleri Enstitüsü, Ankara.

*Turan, E. (2009). Piyanoda pedal kullanma teknikleri. (Yayımlanmamış yüksek lisans tezi). Hacettepe Üniversitesi Sosyal Bilimler Enstitüsü, Ankara.

*Tuzcu, Ö. (2016). Piyano eğitiminde özdüzenlemeli ögrrenme ve ögrenme stilleri ile akademik başarı arasındaki ilişki. (Yayımlanmamış doktora tezi). Marmara Üniversitesi Eğitim Bilimleri Enstitüsü, İstanbul.

*Tuzkaya, G. (2013). R.Schumann'ın Hayatı ve yaratıcılı̆̆l, Op.54 piyano konçertosunun incelenmesi. (Yayımlanmamış sanatta yeterlik tezi). Hacettepe Üniversitesi Güzel Sanatlar Enstitüsü, Ankara.

*Tüfekçi, K. (2010). Gaziosmanpaşa Üniversitesi Eğitim Fakültesi Güzel Sanatlar Eğitimi Bölümünde mevcut piyano durumunun değerlendirilmesi. (Yayımlanmamış yüksek lisans tezi). Cumhuriyet Üniversitesi Sosyal Bilimler Enstitüsü, Sivas.

*Türkmen, N. (2008). Müzik ögretmeni adaylarının piyanoda deşifre çalabilme düzeyleri üzerine bir çalışma. (Yayımlanmamış yüksek lisans tezi). Gazi Üniversitesi Eğitim Bilimleri Enstitüsü, Ankara.

*Uçar, M. (2015). 5-9 yaş aralı̆̆ındaki çocukların piyano ĕgitiminde öğrenmeyi sağlayıcı ve destekleyici görsel materyal geliştirme. (Yayımlanmamış yüksek lisans tezi). Cumhuriyet Üniversitesi Sosyal Bilimler Enstitüsü, Erzurum.

*Umuzdaş, M. S. (2007). Gazi Eğitim Fakültesi Müzik Öğretmenliği programı piyano ögrencilerinin vize ile final süreci arasındaki kaygı düzeylerinin başarı düzeylerine göre incelenmesi. (Yayımlanmamış yüksek lisans tezi). Gazi Üniversitesi Eğitim Bilimleri Enstitüsü, Ankara.

*Umuzdaş, M. S. (2010). Piyano ĕgitiminde süreç ve ürün değerlendirilmesinin öğrencilerin erişi düzeylerine etkisi. (Yayımlanmamış doktora tezi). Gazi Üniversitesi Eğitim Bilimleri Enstitüsü, Ankara.

*Uzar, A. Ç. (2011). İgor Stravinski’nin yeni klasikçi anlayışı: "Piyano ve Üflemeliler İçin Konçertosu" ve "Serenade In A" eserlerinin incelenmesi. (Yayımlanmamış sanatta yeterlik tezi). Anadolu Üniversitesi Güzel Sanatlar Enstitüsü, Eskişehir.

*Uzun, M. G. (2007). Bela Bartok iki piyano ve perküsyon için Sonat'in incelenmesi. (Yayımlanmamış yüksek lisans tezi). İstanbul Üniversitesi Sosyal Bilimler Enstitüsü, İstanbul.

*Uzun, N. B. (2006). Van AGSL'de piyano ögretiminde ögrrencilerin algılarına göre üç tekniğin incelenmesi. (Yayımlanmamış yüksek lisans tezi). Van Yüzüncü Yıl Üniversitesi Sosyal Bilimler Enstitüsü, Van.

*Uzunarslan, D. M. (2010). Cesar Franck La Majör Keman ve Piyano Sonatı'nın form analizi ve teknik çalışma kılavuzu. (Yayımlanmamış yüksek lisans tezi). Mimar Sinan Güzel Sanatlar Üniversitesi Sosyal Bilimler Enstitüsü, İstanbul.

*Uzuner, Ö. (2001). R. Schumann'ın 'Gençlik Albümü'nün piyano eğitimindeki yeri ve önemi. (Yayımlanmamış yüksek lisans tezi). Gazi Üniversitesi Fen Bilimleri Enstitüsü, Ankara. 
*Ünal Akbulut, E. C. (2010). Başlangıç piyano eğitimi için düzenlenmiş Türk ezgileri. (Yayımlanmamış doktora tezi). İstanbul Teknik Üniversitesi Sosyal Bilimler Enstitüsü, İstanbul.

*Ünal, F. (1998). Scriabin'in piyano sonatlarının incelenmesi. (Yayımlanmamış yüksek lisans tezi). İstanbul Üniversitesi Sosyal Bilimler Enstitüsü, İstanbul.

*Ünal, İ. (2006). 6-8 yaş çocukları için piyano eğitimi veren kurumlarda ögretmenlerin başlangıç aşamasında, piyano öğretim yöntemlerinden biri olarak yaratıcı dramaya ilişkin görüşleri. (Yayımlanmamış yüksek lisans tezi). Dokuz Eylül Üniversitesi Eğitim Bilimleri Enstitüsü, İzmir.

*Ünal, Z. O. (2008). Probleme dayal öğrenme modelinin piyano ve öğretimi alanındaki yeterlilik algısına etkisi. (Yayımlanmamış doktora tezi). Marmara Üniversitesi Fen Bilimleri Enstitüsü, İstanbul.

*Ünlü, L. (2014). Piyano eğitiminde video destekli öğretim yönteminin çağdaş Türk müziği eserlerini seslendirmedeki etkisi. (Yayımlanmamış yüksek lisans tezi). Atatürk Üniversitesi Eğitim Bilimleri Enstitüsü, Erzurum.

*Yalçınkaya, B. (2010). Ludwig van Beethoven Op.11 Klarinet, Viyolonsel ve Piyano için Trio, Claude Debussy Première Rhapsodie, Igor Stravinski 3 parça ve Carl Nielsen Fantasy'nin Klarinet Edebiyatı'ndaki yerlerinin incelenmesi. (Yayımlanmamış yüksek lisans tezi). Mimar Sinan Güzel Sanatlar Üniversitesi Sosyal Bilimler Enstitüsü, İstanbul.

*Yaman, O. (2015). Piyano ile eşlikleme becerisinin caz müziği armonisi ile birlikte geliş̧tirilmesi üzerine aşamalı bir çalışma modeli önerisi. (Yayımlanmamış yüksek lisans tezi). Necmettin Erbakan Üniversitesi Eğitim Bilimleri Enstitüsü, Konya.

*Yaşmut, B. (2013). Piyano eğitiminin müziksel işitme, okuma ve yazma davranışlarına etkisi. (Yayımlanmamış yüksek lisans tezi). Ondokuzmayıs Üniversitesi Eğitim Bilimleri Enstitüsü, Samsun.

*Yazgan, E. (2016). Ulvi Cemal Erkin'in Piyanolu Beşli eserine yönelik bir inceleme. (Yayımlanmamış yüksek lisans tezi). Yaşar Üniversitesi Sosyal Bilimler Enstitüsü, İzmir.

*Yazıcı, T. (2014). Problem çözme becerisinin başlangıç seviyesi piyano ögretiminde kullanımı ve etkililiği. (Yayımlanmamış doktora tezi). Necmettin Erbakan Üniversitesi Eğitim Bilimleri Enstitüsü, Konya.

*Yeşil, Y. (2013). Güzel sanatlar ve spor liseleri 9. sinıf piyano ders kitabinın ögrretmen görüşleri doğrultusunda incelenmesi. (Yayımlanmamış yüksek lisans tezi). Niğde Üniversitesi Eğitim Bilimleri Enstitüsü, Niğde.

*Yıkılmazoğlu, A. (2006). Anadolu Güzel Sanatlar Liseleri, lise III müzik sınıfinda okuyan yatılı ve gündüzlü öğrencilerin piyano başarıları arasındaki farklar. (Yayımlanmamış yüksek lisans tezi). Abant İzzet Baysal Üniversitesi, Sosyal Bilimler Enstitüsü, Bolu.

*Yılmaz, G. (2006). Güzel Sanatlar Lisesine yeni başlayan piyano öğrencilerinin biyolojik, psikolojik ve müzikal yönden incelenmesi. (Yayımlanmamış yüksek lisans tezi). Trakya Üniversitesi Sosyal Bilimler Enstitüsü, Edirne.

*Yılmazlar, E. (2004). Müzik öğretmeni adaylarının başlangıç piyano öğretiminde uyguladıklarl yöntem ve tekniklerin değerlendirilmesi. (Yayımlanmamış yüksek lisans tezi). Selçuk Üniversitesi Sosyal Bilimler Enstitüsü, Konya.

*Yiğit, E. E. (2015). Dmitri Shostakovich' in piyano konçertolarının form özellikleri ve piyano tekniği açılarından incelenmesi. (Yayımlanmamış yüksek lisans tezi). Necmettin Erbakan Üniversitesi Eğitim Bilimleri Enstitüsü, Konya. 
*Yokuş, H. (2005). Ülkemizde Türk Halk müziği kaynakl piyano eserlerinin piyano eğitiminde uygulanabilirliğinin değerlendirilmesi. (Yayımlanmamış yüksek lisans tezi). Uludağ Üniversitesi Sosyal Bilimler Enstitüsü, Bursa.

*Yokuş, H. (2009). Piyano ĕgitiminde öğrenme stratejilerinin kullanılmasına yönelik etkinliklerin performans başarısına ve üstbilişsel farkındalığa etkisi. (Yayımlanmamış doktora tezi). Marmara Üniversitesi Eğitim Bilimleri Enstitüsü, İstanbul.

*Yücetoker, İ. (2009). Müzik eğitimi anabilim dalı piyano öğretim elemanlarının ve ögrencilerinin mevcut piyano eğitiminin durumuna ilişkin görüşleri. (Yayımlanmamış yüksek lisans tezi). Selçuk Üniversitesi Sosyal Bilimler Enstitüsü, Konya.

*Yüksel, K. (2010). Piyano eşlikli şan performansinda eşlikçinin algisal ve psikomotor becerileri, deneyimi ve piyanistik düzeyinin zamanlama uyumuyla ilişkisi. (Yayımlanmamış doktora tezi). Gazi Üniversitesi Eğitim Bilimleri Enstitüsü, Ankara.

*Yüksel, M. (2003). L. V. Beethoven'in piyano sonatlarının öğretimine yönelik bir "bütüncül analiz yöntemi”. (Yayımlanmamış doktora tezi). Gazi Üniversitesi Eğitim Bilimleri Enstitüsü, Ankara.

*Zeren, D. (2012). Güzel Sanatlar ve Spor Liseleri'nin müzik bölümlerinde piyano eğitimi sürecinde Türk müziği makam dizilerinin kullanilma durumlarına yönelik bir araştırma. (Yayımlanmamış yüksek lisans tezi). Erciyes Üniversitesi Güzel Sanatlar Enstitüsü, Kayseri.

*Zeybek, A. (2013). Keman ve piyano çalan müzisyenlerde gövde stabilite ve enduransının ă̆r ve yorgunluk üzerine etkisi. (Yayımlanmamış yüksek lisans tezi). Hacettepe Üniversitesi Sağlık Bilimleri Enstitüsü, Ankara.

\section{ETIKK ve BİLIMSEL İLKELER SORUMLULUK BEYANI}

$\mathrm{Bu}$ çalışmanın tüm hazırlanma süreçlerinde etik kurallara ve bilimsel atıf gösterme ilkelerine riayet edildiğini yazar(lar) beyan eder. Aksi bir durumun tespiti halinde Afyon Kocatepe Üniversitesi Sosyal Bilimler Dergisi'nin hiçbir sorumluluğu olmayıp, tüm sorumluluk makale yazarlarına aittir. 